\title{
MIECZYSŁAW STOLARCZYK
}

Katowice

\section{Polska i Niemcy wobec polityki wschodniej Unii Europejskiej i stosunków z Rosją w pierwszej dekadzie XXI wieku ${ }^{1}$}

\begin{abstract}
Wstęp
Republika Federalna Niemiec należała do tej grupy państw, które na wszystkich etapach integracji zachodnioeuropejskiej po II wojnie światowej uczestniczyły w mniej lub bardziej udanych przedsięwzięciach z zakresu integracji politycznej. Współuczestniczyła m.in. w zakończonych niepowodzeniem pracach nad utworzeniem Europejskiej Wspólnoty Obronnej oraz współtworzyła Europejską Współpracę Polityczną. Była też główną inicjatorką utworzenia Wspólnej Polityki Zagranicznej i Bezpieczeństwa (WPZiB) w ramach II filaru traktatu z Maastricht. W latach dziewięćdziesiątych XX wieku należała do najbardziej konsekwentnych zwolenników rozwoju Europejskiej Tożsamości Bezpieczeństwa i Obrony, a od 1999 r. zaangażowała się w rozwijanie Europejskiej Polityki Bezpieczeństwa i Obrony (EPBiO), która to koncepcja zakłada zwiększanie potencjału obronnego UE. RFN na każdym z kolejnych etapów rozwoju WPZiB wysuwała inicjatywy na rzecz jej wzmocnienia, proponując jej uwspólnotowienie ${ }^{2}$. Ze względu na odgrywaną przez Niemcy rolę mocarstwa europejskiego, także o coraz większych ambicjach pozaeuropejskich, RFN wykazywała zainteresowanie wszystkimi kierunkami WPZiB. Jednakże Niemcy, angażując się w realizację przyjętych ustaleń w ramach WPZiB na wszystkich kierunkach realizacji tej polityki, największe zaangażowanie wykazywały w jej kształtowaniu wobec Europy Środkowej i Wschodniej, Bałkanów Zachodnich oraz Stanów Zjednoczonych i Kanady.

W przeciwieństwie do Niemiec, Polska uzyskała formalne i faktyczne możliwości wpływania na poszczególne płaszczyzny integracji w ramach UE, w tym na kształtowanie WPZiB na kierunku wschodnim, dopiero w połowie 2004 r., z chwilą uzyskania członkostwa w UE (1 V 2004). Przedstawiciele kolejnych polskich rządów deklarując poparcie dla rozwoju WPZiB na wszystkich kierunkach realizacji tego procesu ${ }^{3}$, największe zainteresowanie wykazywali współkształtowaniem wymiaru wschodniego

1 Niniejsze opracowanie jest w niewielkim tylko stopniu zmodyfikowanym fragmentem książki autora pt. Zbieżność i różnice interesów w stosunkach polsko-niemieckich w latach 1989-2009, która znajduje się w końcowej fazie procesu wydawniczego w Wydawnictwie Uniwersytetu Śląskiego w Katowicach.

2 R. Zięba, Rola Niemiec w polityce zagranicznej i bezpieczeństwa Unii Europejskiej, „Przegląd Zachodni" 2007, nr 2.

3 Szerzej na temat głównych kierunków realizacji WPZiB zob. R. Zięba, Wspólna Polityka Zagraniczna i Bezpieczeństwa Unii Europejskiej, Warszawa 2007.
\end{abstract}


UE. Decydenci polskiej polityki zagranicznej aspirowali, m.in. ze względu na geopolityczne usytuowanie Polski, do współkreowania WPZiB wobec swoich najbliższych sąsiadów na wschodzie, a nawet uczynienia z tego swojej specjalności ${ }^{4}$.

Celem opracowania jest ukazanie cech najbardziej charakterystycznych polityki wschodniej Niemiec i Polski w kontekście ich dążeń, jak i pozostałych państw członkowskich UE, do wypracowywania wspólnej unijnej polityki wschodniej. Na tej podstawie autor stara się wskazać na zbieżność i różnice interesów występujące w koncepcji i praktyce polskiej i niemieckiej polityki wschodniej, szczególnie w drugiej połowie pierwszej dekady XXI wieku. Akcent został postawiony na ukazaniu różnic w polityce Polski i Niemiec wobec Rosji realizowanej przez każde z tych państw zarówno w wymiarze bilateralnym, jak i wymiarze wielostronnym, w tym poprzez przedsięwzięcia podejmowane w ramach WPZiB UE.

\section{Rosja w polityce wschodniej Unii Europejskiej}

Dla Niemiec i dla pozostałych państw unijnych w realizowanej przez wymiar wschodni WPZiB (wymiar wschodni polityki UE) ${ }^{5}$ czy w ramach Europejskiej Polityki Sąsiedztwa ${ }^{6}$ na kierunku wschodnim najważniejszym partnerem była Federacja Rosyjska, zarówno w płaszczyźnie politycznej i bezpieczeństwa, jak i w dziedzinie gospodarczej ${ }^{7}$. Ze względu na rolę, jaką nadawano Rosji w polityce wschodniej UE, często relacje te określano w kategoriach strategicznego partnerstwa ${ }^{8}$. Mimo że formuła ,partnerstwo strategiczne" nie obejmowała swoim zasięgiem wszystkich dziedzin rosyjsko-unijnych relacji i w wielu obszarach miała charakter deklaratywny ${ }^{9}$, Rosja była postrzegana przez państwa UE jako jeden z najważniejszych uczestników w kształtowaniu systemu bezpieczeństwa międzynarodowego w pozimnowojennej Europie. Była jednym z najważniejszych partnerów UE w wymianie handlowej ${ }^{10}$, przede wszystkim zaś w dziedzinie surowców energetycznych, a tym samym w dziedzinie bezpieczeństwa energetycznego ${ }^{11}$. Dostarczała znaczne ilości surowców energetycznych (w roku

4 Jeszcze przed formalnym członkostwem Polski w UE rozpoczęła się w naszym kraju debata na temat współkształtowania przez Polskę wymiaru wschodniego UE. Zob. , Wymiar wschodni” UE - szansa czy idee fixe polskiej polityki?, red. P. Kowal, Warszawa 2002.

5 Zob. E. Stadtmüller, Unia Europejska i regionalny governance. Wymiar wschodni, „Przegląd Zachodni” 2005, nr 4; B. Piskorska, Wymiar wschodni Unii Europejskiej, Torun 2008.

${ }^{6}$ Zob. P. J. Borkowski, Polityka sqsiedztwa Unii Europejskiej, Warszawa 2009.

7 B. Piskorska, Wymiar wschodni Unii Europejskiej..., s. 309 i n.; A. Warkotsch, Die Nachbarschaftspolitik der EU im postsowjetischen Raum, „Aus Politik und Zeitgeschichte” 2007, Nr. 43, s. 1113.

${ }^{8}$ H. J. Spanger, EU-Russland. Was bleibt der strategischen Partnerschaft?, „Internationale Politik und Gesellschaft" 2007, Nr. 2.

9 R. Ambroziak, Dylematy partnerstwa rosyjsko-unijnego, w: Rosja w okresie prezydentury Władymira Putina, red. A. Stępień-Kuczyńska, S. Bieleń, Łódź-Warszawa-Toruń 2008.

${ }_{10}$ W pierwszym półroczu 2008 r. Rosja stała się trzecim w kolejności partnerem handlowym UE po Stanach Zjednoczonych i Chinach. Zob. M. Raś, Szanse i możliwości realizacji czterech „, wspólnych przestrzeni" w perspektywie XXI wieku, w: Stosunki Rosji z Unia Europejska, red. S. Bieleń, K. Chudoliej, Warszawa 2009, s. 73.

${ }^{11}$ Szerzej zob. M. Kaczmarski, Bezpieczeństwo energetyczne Unii Europejskiej, Warszawa 2010. 
2005 udział Rosji w unijnym imporcie gazu wynosił ok. 40\% i był mniejszy o ok. 10\% w stosunku do roku 2000) ${ }^{12}$ i metali, chociaż stopień uzależnienia gospodarek poszczególnych państw członkowskich UE od rosyjskich dostaw gazu i ropy był wielce zróżnicowany. Przykładowo, w roku 2004 udział eksportowanego przez Roję gazu w ogólnym imporcie tego surowca wynosił w przypadku Estonii i Finlandii - 100\%, Weggier $-85 \%$, Grecji $-80 \%$, Austrii $-77 \%$, Czech i Polski - 69\%, Niemiec $-41 \%$, Włoch $-35 \%$, Francji $-30 \%{ }^{13}$. Nieco inne dane znajdują się w opracowaniu Kamili Pronińskiej $^{14}$.

Rynek rosyjski, wraz z poprawą sytuacji gospodarczej Rosji po roku 1999 i związanym z tym wzrostem poziomu życia społeczeństwa rosyjskiego, był coraz bardziej znaczącym dla państw UE rynkiem zbytu. Dla Rosji, Unia Europejska była głównym partnerem handlowym ${ }^{15}$, bardzo ważnym inwestorem oraz źródłem potrzebnych dla modernizacji gospodarki wzorów organizacyjnych i technologii. Gospodarki Rosji i państw członkowskich UE były w dużym stopniu wobec siebie komplementarne (UE była mocarstwem przemysłowym, a Rosja - mocarstwem surowcowym). W ocenie Emanuela Todda, pod tym względem interesy Europy i Rosji się uzupełniają, a Rosja absolutnie nie posiada środków, które pozwoliłyby jej stać się groźnym mocarstwem w Europie ${ }^{16}$. Zdaniem Pierre Hassnera, Rosja znów staje się trudnym, lecz niezbędnym partnerem Zachodu ${ }^{17}$. Oprócz wymienionych, pojawiały się w tym samym czasie opinie, że wraz ze wzrostem siły Rosji, między Unią Europejską a Rosją i między Stanami Zjednoczonymi a Rosją bardzo prawdopodobne jest narastanie poważnych kontrowersji jako przejawu starej rywalizacji między liberalizmem a autorytaryzmem ${ }^{18}$.

Ze względu na strukturę rosyjsko-unijnej wymiany handlowej, występowała znacząca asymetria jakościowa na niekorzyść Rosji. W eksporcie rosyjskim na rynki unijne dominowały surowce energetyczne, a w eksporcie Unii do Rosji - produkty wysoko

12 M. Leonard, N. Popescu, Rachunek sit w stosunkach Unia Europejska - Rosja, Londyn-Warszawa 2008, s. 19.

${ }_{13}$ B. Molo, Znaczenie Rosji dla bezpieczeństwa energetycznego Niemiec, „Krakowskie Studia Międzynarodowe” 2006, nr 4 (III), s. 248; zob. S. Gardocki, Prymat energetyczny Rosji i odpowiedź Unii Europejskiej, w: Stosunki Rosji z Uniq Europejskq...; R. Götz, Energieexporte als aussenpolitisches Instrument?, „Neue Gesellschaft. Frankfurter Hefte” 2008, Nr. 6, s. 30-33.

${ }^{14}$ K. Pronińska, Strategie bezpieczeństwa energetycznego państwa na przykladzie wybranych krajów UE, w: Państwo w teorii i praktyce stosunków międzynarodowych, red. M. Sułek, J. Symonides, Warszawa 2009, s. 277.

15 Występowała bardzo wyraźna asymetria na niekorzyść Rosji we wzajemnym udziale wymiany handlowej Rosji i UE. W roku 2006 udział UE w eksporcie towarów z FR wynosił 49\%, a w imporcie $55 \%$. Natomiast w handlu zewnętrznym Unii eksport do Rosji to 6\%, a import 9\%. M. Czajkowski, Miejsce UE w polityce zagranicznej Federacji Rosyjskiej-uwarunkowania, zatożenia, pola konfliktu i obszary wspótpracy, „Krakowskie Studia Międzynarodowe” 2008, nr 4 (V), s. 97.

${ }_{16}$ Czego powinna bać się Europa? Rozmowa Emanuela Todda z Zdzistawem Krasnodębskim, „Dziennik. Europa - Tygodnik Idei”, 1 III 2008. W ocenie Richarda Pipesa Rosja jest bardzo słaba. Dlatego kraje takie jak Polska nie powinny obawiać się zagrożenia z jej strony. Samo prężenie muskułów jeszcze nie wystarczy. Na Rosję - przekonywał Pipes - trzeba patrzeć realistycznie, bez lęku i nadmiernych uprzedzeń, ale i baz naiwności. Wywiad z Richardem Pipesem, „Dziennik. Europa - Tygodnik Idei”, 8 III 2008.

${ }_{17}$ P. Hassner, Stulecie niepewności, „Dziennik. Europa - Tygodnik Idei”, 8 III 2008.

18 R. Kagan, Powrót historii i koniec marzeń, Poznań 2009. 
przetworzone, głównie maszyny i urządzenia oraz chemikalia ${ }^{19}$. W 2005 roku Rosja miała ponad 50 mld euro nadwyżki w bilansie handlowym z UE, na co wielki wpływ miały zwyżkujące wówczas na światowych giełdach ceny gazu i ropy naftowej. Jedną z wielu asymetrycznych współzależności występujących między Unią a Rosją na początku XXI wieku było z jednej strony znaczne uzależnienie państw unijnych od surowców energetycznych Rosji (zdecydowana przewaga Rosji w posiadanych surowcach energetycznych $)^{20}$, z drugiej zaś zdecydowana przewaga potencjału gospodarczego UE wobec Rosji (prawie 15 razy większy), demograficznego (liczba ludności UE była 3,5 razy większa od potencjału demograficznego Rosji). Natomiast wydatki na obronność państw UE były siedmiokrotnie wyższe niż rosyjskie ${ }^{21}$. W przyjętych 22 maja 2003 roku przez rząd rosyjski założeniach Strategii Energetycznej Federacji Rosyjskiej do 2020 roku przewidywano dalszy wzrost dostaw przez rosyjskie koncerny gazu i ropy do $\mathrm{UE}^{22}$.

Podstawą formalnoprawną współpracy Unii z Rosją było podpisane 24 czerwca 1994 r. „Porozumienie o partnerstwie i współpracy pomiędzy Unią Europejską a Federacją Rosyjską” („Partnership and Cooperation Agrement”) (PCA). W porozumieniu do głównych celów współpracy unijno-rosyjskiej w płaszczyznach politycznej, gospodarczej, finansowej, prawnej, naukowo-technicznej i humanitarnej zaliczono m.in.: stworzenie stosownych ram do dialogu politycznego, promocja handlu i inwestycji oraz harmonijnych stosunków ekonomicznych, wzmocnienie wolności politycznych i ekonomicznych, wsparcie wysiłków Rosji na rzecz konsolidacji jej demokracji i rozwoju gospodarki rynkowej, stworzenie niezbędnych warunków do przyszłego ustanowienia strefy wolnego handlu pomiędzy Wspólnotą a Rosją. Główną formą rozwoju dialogu politycznego między UE a Rosją stały się dwukrotne w ciągu roku spotkania prezydenta FR oraz przewodniczącego Rady UE i Komisji Europejskiej z udziałem Wysokiego Przedstawiciela ds. Wspólnej Polityki Zagranicznej i Bezpieczeństwa ${ }^{23}$. Większość z tych celów została rozwinięta w pierwszej w historii WPZiB wspólnej strategii, która została zaadresowana do Rosji. Ogłoszono ją podczas prezydencji niemieckiej, w czasie szczytu UE w Kolonii 4 czerwca 1999 roku. W strategii stwierdzono

19 P. Żurawski vel Grajewski, Polityka Unii Europejskiej wobec Rosji a interesy Polski 1991-2004, Kraków-Warszawa 2008, s. 387 i n.

20 Rosja zajmowała pierwsze miejsce pod względem wielkości zasobów gazu ziemnego i pierwsze miejsce w świecie wśród producentów i eksporterów gazu; posiadała drugie co do wielkości, po USA, udokumentowane zasoby węgla kamiennego; zajmowała 7-8 miejsce w świecie (po państwach Zatoki Perskiej i Wenezueli) pod względem rozpoznanych złóż zasobów ropy i była pierwszym bądź drugim (w niektórych latach), po Arabii Saudyjskiej, eksporterem ropy naftowej. Zob. S. Gardocki, Prymat energetyczny Rosji..., s.170-171.

${ }_{21}$ M. Leonard, N. Popescu, Rachunek sit w stosunkach Unia Europejska-Rosja...., s. 18-19.

22 Pojawiały się także prognozy, że ze względu na brak modernizacji infrastruktury wydobywczej i transportowej, brak odpowiedniej ilości środków finansowych, wyczerpywanie się niektórych złóż, błędów w polityce państwa wobec sektora energetycznego, dojdzie do spadku eksportu przez Rosję gazu i ropy. Zob. B. Molo, Polityka bezpieczeństwa energetycznego Federacji Rosyjskiej, w: Międzynarodowe bezpieczeństwo energetyczne w XXI wieku, red. E. Cziomer, Kraków 2008.

23 Porozumienie o partnerstwie i współpracy pomiędzy UE a FR weszło w życie 1 grudnia $1997 \mathrm{r}$. Zawarte zostało na dziesięć lat z możliwością jego przedłużenia. Na mocy protokołu do układu z 27 kwietnia 2004 r. jego postanowienia rozciągnięto na nowe kraje członkowskie UE. Szerzej zob. P. Żurawski vel Grajewski, Polityka Unii Europejskiej wobec Rosji..., s. 43 i n. 
m.in., że celami strategicznymi UE wobec Rosji jest stabilna, otwarta i pluralistyczna demokracja w Rosji i utrzymanie stabilności w Europie przez zintensyfikowanie współpracy z Rosją ${ }^{24}$. Na podstawie przyjętej strategii stosunki unijno-rosyjskie miały zostać podniesione na wyższy poziom, stanowiąc wstęp do rozwoju ich kolejnego etapu w ramach tzw. strategicznego partnerstwa między stronami ${ }^{25}$. Cele te zawierała także kolejna forma instytucjonalizacji stosunków UE-Rosja, jaką było przyjęcie przez Unię w roku 2003 koncepcji „czterech wspólnych przestrzeni” - w gospodarce, sprawach wewnętrznych, bezpieczeństwie zewnętrznym i edukacji ${ }^{26}$. Jednakże mimo przyjmowanych w kolejnych latach przez UE dokumentach mających symbolizować rozwój współpracy unijno-rosyjskiej we wszystkich dziedzinach, wiele założeń miało nadal charakter deklaratywny. W rzeczywistości, mając na uwadze charakter ustroju politycznego w Rosji, w tym odchodzenie administracji prezydenta Władimira Putina od budowy podstaw demokracji w Rosji w kierunku rozwiązań autorytarnych (,demokracji sterowanej”, „dyktatury prawa” czy „suwerennej demokracji”) oraz mając na uwadze relacje dwustronne Rosji z największymi państwami UE, za trafny można uznać wniosek, że demokratyzacja Rosji była dla państw członkowskich UE rzeczą pożądaną, ale nie priorytetową. Jak pisał Przemysław Żurawski vel Grajewski, priorytetem polityki wschodniej UE w owym czasie nie były (wbrew poprawnym politycznie deklaracjom) demokratyzacja, poszanowanie praw człowieka czy budowa gospodarki rynkowej na obszarze WNP. Była nim natomiast stabilizacja Rosji, tzn. wspieranie politycznej stabilności państwa rosyjskiego jako chroniącej przed masowym napływem uchodźców i emigrantów oraz niekontrolowanym rozwojem przestępczości i takiejże proliferacji materiałów rozszczepialnych, a także jako gwarantującej stabilność dostaw surowców energetycznych ${ }^{27}$.

Doktrynalną podstawą założeń polityki rosyjskiej wobec UE była przyjęta pod koniec 1999 roku „Strategia rozwoju stosunków Federacji Rosyjskiej z Unią Europejską w perspektywie średnioterminowej (2000-2010)". W strategii rozwój stosunków z UE uznany został przez Rosję za priorytet jej polityki zagranicznej. Pogłębione partnerstwo z Unią miało służyć m.in. rozwojowi stosunków gospodarczych, zapobieganiu lokalnym konfliktom w Europie i rozwiązywaniu ich bez użycia siły, realizacji interesów Rosji podczas rozszerzania UE. Rozwój partnerstwa z Unią miał też wzmocnić pozycję Rosji na arenie międzynarodowej i jako głównej siły na obszarze $\mathrm{WNP}^{28}$. Stałym dążeniem strony rosyjskiej w tym okresie było uzyskanie statusu samodzielnego mocarstwa, jednego z kluczowych ośrodków siły w wielobiegunowym systemie międzynarodowym, uznanie Rosji za równoprawnego partnera w dziedzinie bezpieczeństwa międzynarodowego, którego interesy, szczególnie na obszarze WNP będą uwzględniane przez stronę unijną. Unia Europejska jawiła się bowiem Rosji, podobnie jak Rosja Unii, nie tylko jako ważny partner, ale także i konkurent. Rosja i Unia Europejska były wobec

\footnotetext{
24 Szerokie omówienie „Wspólnej strategii UE wobec Rosji” z czerwca 1999 r. zob. P. Żurawski vel Grajewski, Polityka Unii Europejskiej wobec Rosji..., s. 102 i n.

25 J. Starzyk-Sulejowska, Udziat Rosji w procesach partnerstwa, dialogu politycznego i budowania wspólnego bezpieczeństwa z Uniq Europejskq, w: Stosunki Rosji z Uniq Europejskq..., s. 122.

${ }^{26}$ Szerzej zob. M. Raś, Szanse i możliwości realizacji czterech „, wspólnych przestrzeni”...

27 P. Żurawski vel Grajewski, Polityka Unii Europejskiej wobec Rosji..., s. 657.

28 J. Starzyk-Sulejowska, Udziat Rosji w procesach partnerstwa..., s. 123-124.
} 
siebie partnerami, ale i rywalami, współpraca przeplatała się z rywalizacją 29 . Współwystępowaniem elementów współpracy i rywalizacji, występowaniem dłuższych bądź krótszych okresów „ochłodzenia” i „odwilży” w relacjach unijno-rosyjskich naznaczony był cały okres pozimnowojenny ${ }^{30}$.

Z chwilą rozszerzenia UE w roku 2004 Rosja stała się jej największym sąsiadem. Nowe, sąsiedzkie usytuowanie geopolityczne rozszerzonej UE i Rosji wpłynęło na wzrost współzależności i na większe „uwrażliwienie” obu stron wobec siebie. Oznaczało to także dalszy wzrost znaczenia Rosji w polityce wschodniej UE oraz wzrost roli UE w polityce Rosji. Po roku 2004, przede wszystkim za sprawą Polski, nastapił wzrost znaczenia obszaru WNP w stosunkach rosyjsko-unijnych. Nastąpił rozwój wymiaru wschodniego Unii Europejskiej, którego jedną z głównych sił sprawczych była Polska. Polska okazała się bowiem wpływowym i najbardziej zdeterminowanym orędownikiem wymiaru wschodniego, którego głos na forum instytucji UE, a zwłaszcza Parlamentu Europejskiego, był przewodnim w tej dyskusji ${ }^{31}$. Jednocześnie po roku 2004 stosunki pomiędzy Rosją a Unią Europejską znacznie się skomplikowały. Częściej niż w latach dziewięćdziesiątych w relacjach unijno-rosyjskich występowały okresy ochłodzenia. Rozszerzenie Unii zbiegło się w czasie z pogorszeniem relacji unijno-rosyjskich $^{32}$. Obok obszarów współpracy pojawiły się nowe, bądź wzmocnione zostały wcześniej już występujące pola sporów i konfliktów. Po roku 2004 w relacjach między Federacją Rosyjską a Unią Europejską oprócz wielu obszarów współpracy występowało jednocześnie, w większym stopniu niż w okresie wcześniejszym, wiele czynników konfliktogennych dotyczących m.in. niewystarczającego przestrzegania w gospodarce rosyjskiej zasad gry rynkowej ${ }^{33}$, regresu w budowie podstaw demokracji w Rosji oraz dążenia rosyjskich grup rządzących do uznania przez Unię rosyjskiej strefy wpływów na obszarze WNP ${ }^{34}$ czy rosyjskiej „strefy odpowiedzialności”. Zaostrzyła się rywalizacja Rosji i Unii Europejskiej w przestrzeni proradzieckiej, gdzie interesy polityczne

29 S. Bieleń, Tożsamość europejska Rosji-zwiqzki i różnice cywilizacyjno-kulturowe, w: Stosunki Rosji z Uniq Europejska..., s. 19 i n.

30 Szerzej zob. A. Stępień-Kuczyńska, M. Słowikowski, Unia Europejska a państwa Europy Wschodniej, Warszawa 2008, s. 44 i n.; B. Łomiński, Unia Europejska w rosyjskiej polityce zagranicznej, w: Kontrowersje poszerzenia Unii Europejskiej dla Europy Środkowej i Wschodniej, red. M. Cichosz, J. Sroka, Warszawa 2004; M. Koczan, Stosunki między Uniq Europejskq a Federacja Rosyjska, w: Polityka zagraniczna i bezpieczeństwa krajów Wspólnoty Niepodległych Państw, red. W. Baluk, Wrocław 2008; S. Sulowski, Stosunki Unia Europejska-Rosja, w: Dyplomacja czy siła? Unia Europejska w stosunkach międzynarodowych, red. S. Parzymies, Warszawa 2009.

31 B. Piskorska, Wymiar wschodni polityki Unii Europejskiej..., s. 452.

32 W literaturze przedmiotu znaleźć można stanowisko, w myśl którego spotkanie Rosja-UE w Petersburgu 31 maja 2003 r. w symboliczny sposób zakończyło fazę ograniczonej w sensie merytorycznym, ale względnie zgodnej współpracy między UE i Federacja Rosyjską w wymiarze politycznym. J. Starzyk-Sulejowska, Udziat Rosji w procesach partnerstwa..., s. 128.

33 Jednym z głównych problemów spornych $w$ stosunkach unijno-rosyjskich były kwestie związane z urealnieniem w oparciu o mechanizmy rynkowe wewnętrznych cen rosyjskiego gazu, zniesienie monopolu Gazpromu na eksport gazu, wprowadzenie swobody tranzytu gazu, umożliwienie budowy gazociągów inwestorom zagranicznym, wyrównanie taryf za transport gazu na rynek wewnętrzny i na eksport, zniesienie w Rosji cen eksportowych na gaz. J. Starzyk-Sulejowska, Udziat Rosji w procesach partnerstwa..., s. 132.

34 M. Czajkowski, Miejsce UE w polityce zagranicznej Federacji Rosyjskiej... 
i gospodarcze Rosji ścierały się coraz bardziej z interesami państw UE i innych podmiotów ${ }^{35}$. Promowanie wzorców zachodniej demokracji przez Zachód na obszarze WNP za pośrednictwem wspierania „kolorowych rewolucji” (,aksamitnych rewolucji”) ${ }^{36}$, które UE traktowała jako poszerzanie przestrzeni stabilności i bezpieczeństwa, strona rosyjska zazwyczaj oceniała jako ingerencję $\mathrm{w}$ wewnętrzne sprawy państw proradzieckich i działania destabilizujące na tym obszarze. Dążenia państw członkowskich UE do zacieśnienia współpracy z Gruzją (po „rewolucji róż” w 2003 r.) i Ukrainą (po „pomarańczowej rewolucji' w 2004 r.), wspieranie przez nich opozycji demokratycznej na Białorusi, były traktowane przez grupy rządzące Rosji w kategoriach zagrożenia dla swoich interesów na tym obszarze. Podobnie postrzegane były działania Unii, zintensyfikowane w drugiej połowie pierwszej dekady XXI wieku, zmierzające do zwiększenia dywersyfikacji dostaw nośników energii i do zmniejszenia uzależnienia gospodarek unijnych od rosyjskiego gazu i rosyjskiej ropy przez budowę nowych gazociagów i ropociagów omijających terytorium Rosji (np. ropociąg Baku-Tbilisi-Ceyhan, łączący Azerbejdżan przez Gruzję z Turcja, czy rurociag Nabucco, który miałby zapewnić tranzyt gazu ziemnego z regionu Morza Kaspijskiego przez kraje Kaukazu Południowego, Turcję, Bułgarię, Rumunię, Węgry i Austrię aż do Europy Zachodniej). Rosja natomiast zaangażowała się w budowę gazociagu północnego (North Stream) i południowego (South Stream). Realizacja tych projektów miała m.in. pozwolić Rosji na utrzymanie roli monopolisty w dostarczaniu gazu z obszaru byłego Związku Radzieckiego do Europy Zachodniej i Południowej ${ }^{37}$.

Rosja dążąc do urynkowienia cen gazu i ropy z państwami $\mathrm{WNP}^{38}$, chcąc wyegzekwować należne jej sumy, często sięgała po tzw. broń gazową, przerywając dostawy gazu do Ukrainy (w styczniu 2006 r. i w latach następnych) ${ }^{39}$ i Białorusi. W praktyce, ze względu na fakt, iż przez Ukrainę i Białoruś biegły gazociaggi i naftociągi zaopatrujące państwa członkowskie UE, dla wielu z nich oznaczało to ograniczenie czy nawet wstrzymanie na kilka dni dostaw rosyjskiego gazu. Na tym tle dochodziło do powtarzających się tzw. minikryzysów w relacjach UE-Rosja w latach 2006-2009. W wyniku nadużywania przez Rosję zarówno do celów ekonomicznych, jak i politycz-

35 S. Kardaś, Wspótpraca i rywalizacja Rosji oraz Unii Europejskiej w przestrzeni proradzieckiej, w: Stosunki Rosji z Uniq Europejskq...; Dyskusja o polityce Unii Europejskiej wobec Rosji, „Polski Przegląd Dyplomatyczny" 2008, nr 1; H. J. Spanger, EU-Russland: Was bleibt von der strategischen Partnerschaft?...

${ }^{36}$ Zob. V. Avioutskii, Aksamitne rewolucje, Warszawa 2007.

37 Zob. B. Molo, Polityka bezpieczeństwa energetycznego Federacji Rosyjskiej...

38 Stopień zaawansowania tego procesu z poszczególnymi państwami WNP motywowany był w dużym stopniu względami politycznymi. Z chwilą obrania przez grupy rządzące Ukrainy, wyłonione w wyniku ,pomarańczowej rewolucji”, wyraźnej opcji prozachodniej, Rosja odeszła od subsydiowania gospodarki ukraińskiej (ok. 3-5 mld dol. rocznie) dzięki sprzedaży Ukrainie gazu i ropy po znacznie niższych cenach od cen światowych, przechodząc stopniowo na ceny rynkowe. Państwa WNP importujące od Rosji gaz i ropę, prowadzące ,przychylną” wobec Rosji politykę płaciły za te surowce znacznie poniżej od cen rynkowych tych surowców. S. Gardocki, Prymat energetyczny Rosji..., s. 196-197. W roku 2008 Rosja zmusiła Ukrainę do płacenia wyższych stawek za gaz ziemny niż w 2007 r. (odpowiednio 179,5 dol. i 130 dol. za $1000 \mathrm{~m}^{3}$ ), co i tak było stawką konkurencyjną w stosunku do ceny, jaką płaciły kraje europejskie -315 dol. za $1000 \mathrm{~m}^{3}$ ). S. Kardaś, Współpraca i rywalizacja Rosji..., s. 242-243.

39 Około 90\% importowanego przez UE z Rosji gazu przepływało przez Ukrainę. 
nych straszaka „broni gazowej”40 znacznie spadła wiarygodność Rosji jako pewnego, stabilnego dostawcy tego surowca dla Unii Europejskiej. Wpłynęło to na przyśpieszenie prac w Unii zmierzających do zwiększenia bezpieczeństwa energetycznego państw członkowskich i wypracowania wspólnej koncepcji bezpieczeństwa energetycznego ${ }^{41}$. Ważnym krokiem na tej drodze było przyjęcie przez Radę Europejską w marcu 2007 roku, w czasie prezydencji niemieckiej, planu działania pod nazwą: Europejska Polityka Energetyczna (EPE), który zapowiadał przyśpieszenie prac w realizacji zintegrowanego unijnego wewnętrznego rynku gazu i energii elektrycznej, wspólnej polityki w zakresie negocjowania i finalizacji porozumienia z Rosja, w dziedzinie nośników energii oraz dalszej dywersyfikacji źródeł energii ${ }^{42}$. W ramach EPE kraje członkowskie UE zachowały nadal swoją suwerenność w zakresie polityki energetycznej, zobowiązując się do podniesienia wydajności energetycznej o $20 \%$, z jednoczesnym dążeniem do dalszej redukcji emisji gazów cieplarnianych do 2020 roku o $20 \%$ oraz zwiększenia odnawialności źródeł energii w ogólnym bilansie energetycznym o $20 \%{ }^{43}$.

W omawianym okresie, do największego schłodzenia relacji Rosji z USA i Unią Europejską doszło w drugiej połowie 2008 roku w związku z konfliktem rosyjsko-gruzińsko-osetyńskim. Wielu polityków zachodnich, w tym prezydent Francji, Nicolas Sarkozy', oceniało użycie siły militarnej przez Rosję wobec Gruzji w tym konflikcie jako uzasadnione, ale zbyt daleko idące i niewspółmierne do zagrożeń ${ }^{44}$. Konflikt wokół Osetii Południowej zdaniem wielu analityków oznaczał, że okres rosyjskich ustępstw geopolitycznych się zakończył i Rosja w sposób bardziej zdecydowany będzie zabiegać o utrzymanie „tradycyjnej strefy interesów”45. Jednocześnie Rosja nie była zainteresowana eskalowaniem powstałego na tym tle napięcia w relacjach z USA i Unią Europejską. Bardzo istotną rolę w doprowadzeniu do rozejmu między stronami konfliktu wokół Osetii Południowej odegrał Nicolas Sarkozy, który w drugiej połowie 2008 roku pełnił funkcję przewodniczącego Rady Europejskiej. Wynegocjował on z prezydentem Rosji, Dmitrijem Miedwiediewem, w czasie rozmów przeprowadzonych w Moskwie 12 sierpnia i 8 września 2008 roku porozumienie pokojowe w sprawie Gruzji. Był to znaczący sukces dyplomacji unijnej.

Pogorszenie stosunków rosyjsko-unijnych spowodowane konfliktem rosyjsko-gruzińskim trwało stosunkowo krótko. Przy tym to „schłodzenie” relacji bardziej było wi-

${ }^{40}$ G. Gromadzki, W. Konończuk, Energetyczna gra. Ukraina, Mołdawia i Białoruś między Unia a Rosja, Warszawa 2007; A. Szeptycki, Polityka Rosji wobec Ukrainy: instrumenty wptywu, „Sprawy Międzynarodowe" 2007, nr 1.

${ }_{41}$ F. Umbach, Europa nächster Kalter Krieg, „Internationale Politik” 2006, nr 2, s. 6-14.

${ }^{42} \mathrm{Na}$ temat trudności związanych z realizacją przez UE wspólnej polityki energetycznej zob. S. Gardocki, Prymat energetyczny Rosji...

43 E. Cziomer, Międzynarodowe bezpieczeństwo energetyczne Niemiec u progu XXI wieku, „,Krakowskie Studia Międzynarodowe" 2007, nr 4(IV), s. 273.

44 R. Beste, U. Klussmann (i inni), Wettlauf zum Tunel, „Der Spiegel”, 15 IX 2008. W raporcie przygotowanym przez międzynarodową komisję pod przewodnictwem szwajcarskiej dyplomatki Heidi Tagliavini winą za wywołanie wojny obarczono Gruzję. Jednocześnie w raporcie stwierdzono, że Rosja przesadziła z reakcją i użyła siły militarnej w stopniu nieproporcjonalnym do zagrożenia. Raport w sprawie konfliktu w Gruzji, „Międzynarodowy Przegląd Polityczny” 2010, nr 1.

45 Wystapienie prezydenta Rosji Dmirtija Miedwiediewa na spotkaniu klubu dyskusyjnego Wałdaj w Moskwie (12 IX 2008), „Gazeta Wyborcza”, 20-21 IX 2008. 
doczne w relacjach UE-Rosja, w zdecydowanie mniejszym zaś stopniu w relacjach dwustronnych Rosji z Niemcami, Francją czy z Włochami. Z upływem czasu coraz powszechniejsza stawała się też opinia, że głównym odpowiedzialnym za konflikt kaukaski w sierpniu 2008 roku był prezydent Gruzji, Michael Saakaszwili, na polecenie którego armia gruzińska rozpoczęła akcję militarną wobec Osetii Południowej, co skutkowało militarnym zaangażowaniem się Rosji po stronie Osetyńczyków ${ }^{46}$. To m.in. sprawiło, że po kilkutygodniowym ,schłodzeniu” relacji Rosji z UE i NATO spowodowanym pięciodniowym konfliktem zbrojnym na Kaukazie, stosunkowo szybko rozpoczęło się przywracanie tej współpracy. Przy czym szybciej ten proces postępował w relacjach UE-Rosja niż w stosunkach NATO-Rosja.

Jednym z głównych celów Rosji w relacjach z UE, podobnie jak w stosunkach z innymi głównymi uczestnikami stosunków międzynarodowych, było dążenie do wzmocnienia dzięki posiadanym środkom ekonomicznym (w tym dzięki coraz częściej stosowanej tzw. broni gazowej - nadużywaniu cen i dostaw gazu dla celów politycznych) i politycznym swojej pozycji międzynarodowej, a zarazem do utrzymania i wzmacniania roli mocarstwa euroazjatyckiego. Grupom rządzącym Rosji zależało na rozwijaniu współpracy z UE, traktowanej jako niezbędny środek służący modernizacji rosyjskiej gospodarki i wzrostowi międzynarodowej roli Rosji, ale bez przyjmowania unijnych standardów ustrojowych i w zakresie praw człowieka. Rosja chciała się europeizować, ale w wybranych obszarach życia społecznego i na własnych, a nie Unii, warunkach (idea „suwerennej europeizacji”) ${ }^{47}$. Prezydent W. Putin i większość rosyjskiej klasy politycznej podkreślali, że Rosja współpracując z UE i innymi państwami, musi uwzględniać i zachować własną specyfikę w polityce i gospodarce. Stanisław Bieleń wskazując na główne pola konfrontacji między Rosją a Unią akcentował, że u ich podstaw znajdowały się różnice cywilizacyjno-kulturowe. Obie strony wychodziły z innych przesłanek aksjologicznych i inaczej widziały cele rozwojowe. Rosja stała na gruncie interesów suwerennego państwa w polityce europejskiej, UE zaś zakładała poszerzanie pola wspólnotowych interesów, dążenie do uniformizacji wzorców zachowań, przestrzegania tych samych standardów i norm ${ }^{48}$. Rosja, podobnie jak Chiny, podchodziła selektywnie do głównych następstw procesów globalizacji w poszczególnych płaszczyznach stosunków międzynarodowych. Akceptowała wzrost współzależności w płaszczyźnie ekonomicznej, lecz jednocześnie pragnęła zachować możliwie najpełniejszą polityczną niezależność, krytycznie podchodząc do lansowanej przez USA i inne państwa Zachodu koncepcji poszerzania „demokratycznej strefy pokoju” przez promowanie zachodnich wzorców demokracji.

Warto nadmienić, że w kolejnych etapach stosunków rosyjsko-unijnych w stanowisku Unii nie pojawiła się propozycja członkostwa Rosji w tej strukturze, nawet w odległej perspektywie. Nigdy też Rosja z taką propozycją wobec UE nie wystapiła. Z tego też m.in. względu UE nie dysponowała wobec Rosji skutecznymi instrumentami nacisku (sankcje ekonomiczne, ze względu na uzależnienie Unii od rosyjskich surowców energetycznych byłyby bronią obosieczną), najskuteczniejszym bowiem instrumentem

„Rocznik Strategiczny 2008/09”, Warszawa 2009, s. 76 i n.

47 M. Leonard, N. Popescu, Rachunek sit..., s. 37.

48 S. Bieleń, Tożsamość europejska Rosji - zwiazki i różnice cywilizacyjno-kulturowe..., s. 24. 
WPZiB wobec wielu państw było - pisał Przemysław Żurawski vel Grajewski - stworzenie perspektywy przystapienia do Unii państwom, które tego sobie życzą i których życzy sobie Unia w swoim gronie, uzależniając członkostwo od spełnienia postawionych warunków ${ }^{49}$.

W wielu opracowaniach wskazywano, że jednym z istotnych czynników sprawczych wzrostu kontrowersji w stosunkach rosyjsko-unijnych po roku 2004 był wpływ na unijną politykę wobec Rosji niektórych z nowo przyjętych do Unii w roku 2004 państw ${ }^{50}$. Miano na uwadze przede wszystkim Polskę, która wniosła do UE trudną sytuację w relacjach z Rosją ${ }^{51}$ i w nieco mniejszym stopniu Litwę, jedyne dwa państwa, które w raporcie autorstwa Marka Leonarda i Nicu Popescu zaliczone zostały, mając na uwadze ich politykę wobec Rosji, do wojowników „nowej zimnej wojny”,52. Wśród 12 nowych państw, które zostały przyjęte w latach 2004-2007 do UE, Polska była państwem największym, tym samym jej wpływ na poszczególne polityki unijne, również na politykę Unii wobec Rosji, był znacznie większy w porównaniu z możliwościami każdego z pozostałych państw w tej grupie. Zarazem Polska była głównym promotorem bardziej stanowczej i krytycznej polityki unijnej wobec Rosji. Cytowani już M. Leonard i N. Popescu pisali: „Polska i Litwa, motywowane rosyjskimi naciskami i niezamkniętymi kwestiami historycznymi, nie przepuściły żadnej okazji do tego, by publicznie skrytykować Rosję. Ich polityczne stosunki z Moskwą są lodowate, co przekłada się na gospodarkę,53. Bezkompromisowa postawa „,wojowników nowej zimnej wojny" wobec Rosji oraz Rosji wobec nich doprowadziła wiele dwustronnych problemów, szczególnie w stosunkach polsko-rosyjskich, do ich „europeizacji”. Problemy te w znacznym stopniu zostały przeniesione na relacje unijno-rosyjskie ${ }^{54}$. Nie był to czynnik, który ułatwiał wypracowanie naprawdę wspólnej i efektywnej polityki UE wobec jej wschodnich sąsiadów. Polska wchodząc do UE wniosła do unijnej polityki wschodniej także swoją „starą” rywalizację między Warszawą a Moskwą/Petersbur-

49 P. Żurawski vel Grajewski, Polityka Unii Europejskiej wobec Rosji..., s. 658-659.

50 S. Parzymies, Wpływ państw członkowskich UE z Europy Środkowej na ksztalt stosunków Unii z Rosja, w: Stosunki Rosji z Uniq Europejskq...; M. Leonard, N. Popescu, Rachunek sit...

${ }_{51}$ Robert Kagan pisał, że „gdy Unia przyjęła Polskę, zaanektowała tym samym polską wrogość i podejrzliwość wobec Rosji (i wobec Niemiec). R. Kagan, Powrót historii i koniec marzeń..., s. 27-28. Zob. Ch. B. Scheffel, Niemcy i Polska wobec Rosji-problemy partnerstwa i sqsiedztwa, „Stosunki Międzynarodowe” 2006, nr 1-2, s. 58.

52 Autorzy raportu wyróżnili wśród 27 państw członkowskich UE pięć różnych postaw wobec Rosji: konie trojańskie (Cypr i Grecja), często bronią na forum UE rosyjskich interesów i nie wahają się wetować wypracowanych przez Unię stanowisk; partnerzy strategiczni (Francja, Hiszpania, Niemcy i Włochy) utrzymują z Rosją „,specjalne stosunki”, które czasami podważają unijną politykę; przyjaźni pragmatycy (Austria, Belgia, Bułgaria, Finlandia, Luksemburg, Malta, Portugalia, Słowacja i Węgry) utrzymują bliskie stosunki z Rosją i są skłonni stawiać własne interesy gospodarcze ponad celami politycznymi UE; chłodni pragmatycy (Czechy, Dania, Estonia, Holandia, Irlandia, Łotwa, Rumunia, Szwecja i Wielka Brytania) również skupiają się na interesach gospodarczych, ale w mniejszym stopniu obawiają się krytykować Rosję (na przykład za łamanie praw człowieka); wojownicy nowej zimnej wojny (Polska i Litwa) utrzymują wrogie stosunki z Rosją i są gotowe użyć prawa weta, by zablokować unijne negocjacje z Rosją. M Leonard, N. Popescu, Rachunek sił..., s. $10-11$.

53 Ibidem, s. 64.

54 Ibidem. 
giem o wpływy i wybór orientacji politycznej przez Ukrainę i Białoruś. Ta fundamentalna polsko-rosyjska sprzeczność interesów została po roku 2004 przeniesiona w pewnym stopniu także na relacje unijno-rosyjskie ${ }^{55}$. Niekiedy wzmacniała ona także dążenia niektórych państw unijnych do bilateralnych uzgodnień z Rosją. W tym miejscu należy zaznaczyć, że rząd premiera Donalda Tuska prowadził mniej konfrontacyjną politykę wobec Rosji w stosunku do tej prowadzonej przez rządy PiS i w stosunku do polityki wschodniej realizowanej przez prezydenta Lecha Kaczyńskiego.

Rosyjskie grupy rządzące odpowiedzialnością za pogorszenie relacji UE-Rosja i bardziej krytyczną politykę Unii wobec Rosji w drugiej połowie pierwszej dekady XXI wieku obarczyły niektóre z nowych państw członkowskich UE, przede wszystkim Polskę i państwa nadbałtyckie. Po stronie rosyjskiej oceniano, że wśród przyjętych z naszego subregionu w roku 2004 państw do UE politykę pragmatyczną wobec Rosji prowadziły Węgry, Czechy i Słowacja. Natomiast Polska i państwa nadbałtyckie postrzegane były jako państwa prowadzące wobec Rosji politykę nieprzychylną czy wręcz wrogą (m.in. ze względu na zaangażowanie Polski i Litwy na rzecz przemian demokratycznych na Ukrainie ${ }^{56}$ i Gruzji oraz w spory Rosji z Łotwą i Estonią na tle zapewnienia praw mniejszości rosyjskiej w tych państwach). Po stronie rosyjskiej Polska postrzegana była także jako forpoczta zachodnich wpływów i obcej cywilizacji oraz promotor katolicyzmu na obszarze poradzieckim ${ }^{57}$.

\section{Niemcy wobec polityki wschodniej UE i stosunków z Rosją}

W okresie rządów G. Schrödera Niemcy zainteresowane były wypracowaniem w ramach tzw. wymiaru wschodniego WPZB koncepcji polityki UE wobec Rosji, Ukrainy, Białorusi i Mołdawii, jednakże największą wagę przywiązywały do intensyfikacji współpracy dwustronnej przede wszystkim z Rosją i w mniejszym stopniu z Ukrainą. W polityce wschodniej UE rząd kanclerza G. Schrödera preferował zasadę Russland zuerst ${ }^{58}$. Natomiast grupy rządzące Rosji nadawały w tym czasie RFN rolę swego rodzaju promotora rozwoju stosunków Rosji z UE. Kanclerz Schröder podkreślał, że strategicznym celem UE wobec Rosji powinno być wspieranie jej europejskiej orientacji, a strategiczne partnerstwo energetyczne z Rosją może w tym zakresie służyć za bardzo silną „europejską kotwicę” rosyjskiej polityki ${ }^{59}$. Również rząd „,wielkiej koalicji" kanclerz A. Merkel, mimo nowych akcentów w polityce wobec Rosji, utrzymał zasadę oparcia relacji unijno-rosyjskich i niemiecko-rosyjskich na formule strategicz-

55 P. Żurawski vel Grajewski, Polityka Unii Europejskiej wobec Rosji..., s. 672.

56 Zaangażowanie polityczne UE w poparcie jednej ze stron ,pomarańczowej rewolucji” na czele z Władymirem Juszczenko i Julią Tymoszenko, było przede wszystkim wynikiem zabiegów polskich polityków, w tym prezydenta Aleksandra Kwaśniewskiego.

57 A. Grajewski, Wyzwania polskiej polityki wschodniej, w: Polityka zagraniczna Polski. Unia Europejska, Stany Zjednoczone. Sasiedzi, red. J. Czaputowicz, Warszawa 2008, s. 303.

58 B. Koszel, Polska i Niemcy w Unii Europejskiej. Pola konfliktów i płaszczyzny wspótpracy, Poznań 2008, s. 152 i n.

59 J. Sokołowski, Jak demokrata z demokrata, „Rzeczpospolita”, 11-12 XII 2004. Szerzej zob. A. Rahr, Schröders Russland-Politik, „Interantionale Politik” 2004, nr 9. 
nego partnerstwa. Po stronie niemieckiej podkreślano, podobnie jak w okresie poprzednim, że w interesie Niemiec leży stabilizacja i modernizacja Rosji, rozbudowa stosunków gospodarczych (szczególnie w dziedzinie energii) i udział Rosji w rozwiązywaniu problemów globalnych, $\mathrm{w}$ tym $\mathrm{w}$ walce $\mathrm{z}$ terroryzmem międzynarodowym ${ }^{60}$.

Niemcy bardzo aktywnie zabiegały o to, by wzmocnić współpracę między UE a Rosją w coraz to nowych dziedzinach. Rząa G. Schrödera wykazywał też duże zrozumienie dla dążeń Rosji, by w procesie rozszerzenia UE w roku 2004 o 10 nowych państw, w tym Polskę i Litwę, Unia uwzględniła związane z tym jej interesy, przede wszystkim dotyczące obwodu kaliningradzkiego (np. obawy Rosji o powstanie utrudnień w ruchu osobowym $^{61}$ oraz tranzycie rosyjskich towarów do tej enklawy). Był to istotny problem dla Rosji i UE chociażby z tego względu, że wraz z rozszerzeniem UE w 2004 r. integralna część Federacji Rosyjskiej, jaką był obwód kaliningradzki, z wszystkich stron na lądzie sąsiadowała z państwami członkowskimi UE. W polskiej publicystyce oraz w wystapieniach wielu polskich polityków te działania Rosji były często interpretowane jako sprzeciw Rosji wobec rozszerzenia UE.

Dyplomacja niemiecka, pomimo początkowej rezerwy wobec tej koncepcji (m.in. ze względu na preferowanie stosunków z Rosją, a także w obawie o ekonomiczne koszty jej realizacji $)^{62}$, odegrała także jedną z głównych ról w przyjętej w roku 2004 przez UE Europejskiej Polityce Sąsiedztwa, zmodyfikowanej i przekształconej w roku 2006 na Nową Europejską Politykę Sąsiedztwa (EPS). Najważniejszym celem tej inicjatywy było zintensyfikowanie współpracy między UE a jej wszystkimi sąsiadami w oparciu o zindywidualizowane plany działania. Europejska Polityka Sąsiedztwa dotyczyła także wymiaru wschodniego. Na tym kierunku obejmowała ona przede wszystkim Ukrainę, Mołdawię a w perspektywie także Białoruś. Z czasem coraz większe znaczenie nadawano w ramach EPS na kierunku wschodnim także subregionowi kaukaskiemu, a przede wszystkim wspieraniu prozachodnich aspiracji Gruzji ${ }^{63}$. Polityka wobec Rosji

${ }^{60}$ Ch. Meier, Die ,grosse Koalition” und die deutsche-russiche Partnerschat: Kontinuität und neue Akzente, „Przegląd Stosunków Międzynarodowych” 2006, nr 2; E. Cziomer, Międzynarodowe implikacje partnerstwa strategicznego Niemcy-Rosja w XXI wieku, w: Zrozumieć współczesność, red. G. Babiński, M. Kapiszewska, Kraków 2009.

${ }_{61}$ W związku ze zbliżającym się terminem wstapienia Polski do UE Polska i Litwa wprowadziły całkowity obowiązek wizowy dla Rosjan (Polska od 1 października 2003 r.). Do tej pory obywatele FR wjeżdżający do Polski mogli przedstawić na granicy vouchery lub zaproszenia (albo pieczątkę służbową $\mathrm{AB}$ ). Decyzja o wprowadzeniu bezwarunkowego obowiązku posiadania wiz napotkała sprzeciw strony rosyjskiej, która uważała, że doprowadzą one do izolacji Obwodu kaliningradzkiego. $\mathrm{Z}$ tego powodu Rosja domagała się też zachowania ruchu bezwizowego między enklawą a Rosją. Rozwiązaniem kompromisowym było przyjęcie tzw. uproszczonego systemu tranzytowego. M. Smoleń, Obwód Kaliningradzki po rozszerzeniu Unii Europejskiej, w: Międzynarodowe implikacje procesu integracji europejskiej dla Polski i Niemiec..., s. 187-188.

${ }_{62}$ M. Falkowski, K-O. Lang, Wspólne zaufanie. Polska, Niemcy i Ukraina w przeobrażajacej się Europie, Warszawa 2004, s. 97.

${ }_{63}$ P. J. Borkowski, Polityka sqsiedztwa Unii Europejskiej..., s. 191 i n.; J. Maliszewska-Nienartowicz, Europejska Polityka Sasiedztwa: cele i instrumenty, „Sprawy Międzynarodowe” 2007, nr 3; B. Woźniak, Europejska Polityka Sasiedztwa: „udawane rozszerzenie” czy niedoceniany instrument?, „Sprawy Międzynarodowe” 2007, nr 3; W. Prismeyer-Tkocz, Niemcy wobec Europejskiej Polityki Sasiedztwa ze szczególnym uwzględnieniem Ukrainy, „Krakowskie Studia Międzynarodowe” 2006, nr 4 (III). 
była realizowana na odrębnych zasadach m.in. ze względu na zdecydowanie większą rolę Rosji w polityce wschodniej UE niż pozostałych państw powstałych na obszarze byłego ZSRR oraz ze względu na aspiracje Rosji do partnerstwa strategicznego z Unią. Władze Rosji uważały Europejską Politykę Sąsiedztwa realizowaną na kierunku wschodnim, a jeszcze bardziej zgłoszoną w roku 2008 przez Polskę i Szwecję inicjatywę Partnerstwa Wschodniego, za kolejny przejaw dążeń UE do rywalizacji o wpływy na obszarze proradzieckim. $Z$ tych m.in. względów, obok preferowanych przez stronę rosyjską innych mechanizmów współpracy z UE, Rosja odrzucała sugestie UE dotyczące jej ewentualnego udziału w EPS. Natomiast inicjatorzy Partnerstwa Wschodniego nie przewidywali w nim udziału Rosji ${ }^{64}$.

Mimo rosnącego zaangażowania Niemiec w działania wielostronne podejmowane przez UE na kierunku rosyjskim, w praktyce, wiodącą rolę w polityce niemieckiej wobec Rosji nadal odgrywały relacje dwustronne. Polityka wschodnia UE wobec Rosji była raczej uzupełnieniem, a nie istotą niemieckiej Russlandpolitik. Szczególnie odnosiło się to do okresu rządów G. Schrödera, który realizował wobec Rosji koncepcję strategicznego partnerstwa, w płaszczyźnie zarówno gospodarczej, jak i politycznej ${ }^{65}$.

W tym miejscu warto przypomnieć, że kolejne rządy niemieckie w okresie pozimnowojennym, popierając konsekwentnie dążenie państw Europy Środkowej do członkostwa w NATO i UE, jednocześnie zabiegały o jak najlepsze stosunki z Federacją Rosyjską. Dla decydentów polityki zagranicznej Niemiec w ich hierarchii ważności Rosja w całym okresie pozimnowojennym zajmowała miejsce daleko w przedzie przed Polską. Rosja ze względu na potencjał demograficzny, obszar, zasoby surowcowe, rynek zbytu dla towarów produkowanych przez gospodarkę niemiecką, potencjał militarny, rolę, jaką odgrywała na obszarze euroazjatyckim, a także z racji tradycji współpracy niemiecko-rosyjskiej była głównym partnerem Niemiec na wschodzie. W niemieckich koncepcjach bezpieczeństwa europejskiego Rosji wyznaczono rolę jednego z głównych jego składników. Niemcy były zainteresowane coraz ściślejszą współpracą Rosji z Unią Europejską (europeizacją Rosji) również z tego względu, że w zacieśnianiu współpracy z Rosją upatrywano bardzo ważny czynnik wpływający na - co prawda powolną, ale stopniową - budowę podstaw demokracji rosyjskiej ${ }^{66}$. Bardzo dobre relacje niemiecko-rosyjskie w okresie rządów kanclerza $\mathrm{H}$. Kohla zostały wzmocnione w okresie rządów kanclerza G. Schrödera, kiedy to w polityce niemieckiej wyznaczono Rosji rolę strategicznego partnera. Mimo nowych, bardziej pragmatycznych akcentów w polityce niemieckiej wobec Rosji po roku 2005, rząd Angeli Merkel podtrzymał formułę strategicznego partnerstwa niemiecko-rosyjskiego. Opowiadał się także za strategicznym partnerstwem Unii Europejskiej z Rosją, co znalazło swój formalny wyraz w porozumieniu koalicyjnym CDU/CSU/SPD z 11 listopada 2005 roku $^{67}$. W praktyce

${ }^{64}$ A. Kremer, Po co potrzebujemy nowego partnerstwa wschodniego?, „Dialog” 2008-2009, nr 85-86.

65 A. Rahr, Schröders Russland-Politik, „Internationale Politik” 2004, nr 9; A. Guział, Miejsce Rosji w polityce zagranicznej RFN a szansa na wspólna politykę wschodnia UE, „Przegląd Zachodni” 2006, nr 2.

${ }^{66}$ H. Zimmermann, Die deutsch-russischen Beziehungen im europaeischen Kontext, „Internationale Politik und Gesellschaft" 2007, Nr. 1.

67 Szerzej zob. A. Guział, Miejsce Rosji w polityce zagranicznej RFN a szanse na wspólna polityke wschodnia UE, „Przegląd Zachodni” 2006, nr 2; E. Cziomer, Polityka zagraniczna Niemiec. 
partnerstwo strategiczne z Rosją realizowane przez RFN po roku 2005 w wymiarze dwu- i wielostronnym dotyczyło przede wszystkim płaszczyzny ekonomicznej, a w mniejszym stopniu niż w okresie wcześniejszym dziedziny politycznej ${ }^{68}$.

$Z$ rządem A. Merkel wiązano w Polsce nadzieje na istotne zmiany w polityce Niemiec wobec Rosji, w tym z odejściem od uprawianej przez G. Schrödera polityki porozumiewania się z Rosja , ,ponad głowami Polaków”. Jednym z najważniejszych przejawów oczekiwanych zmian w polityce rosyjskiej Niemiec miało być uwzględnianie przez rząd A. Merkel polskich interesów w zakresie bezpieczeństwa energetycznego. Domniemywane zmiany w polityce Niemiec wobec Rosji miały jednocześnie prowadzić do wzrostu roli Polski w niemieckiej Ostpolitik. Prognozy te nie okazały się jednak trafne. Mimo wspomnianych nadziei Warszawy kanclerz A. Merkel nie porzuciła planów budowy gazociagu bałtyckiego (mimo głoszonego postulatu, by wobec Rosji UE mówiła jednym głosem) i nie odeszła od realizowanej w niemieckiej polityce wschodniej zasady „najpierw Rosja”. W polityce rządu kanclerz Merkel wobec Rosji zmieniła się nieco forma, bardziej też podkreślano potrzebę uznawania i praktykowania wspólnych wartości demokratycznych, ale główne dotychczasowe cele nie uległy zmianie. Gospodarka nadal stanowiła filar nośny niemiecko-rosyjskiej współpracy bilateralnej ${ }^{69}$. Jednocześnie kanclerz Merkel deklarowała wolę poprawy stosunków z Polską, w tym ściślejszej współpracy z Polską i krajami bałtyckimi. Dla rządu niemieckiego bliskie dobrosąsiedzkie stosunki pomiędzy Niemcami a Polską oraz współpraca strategiczna z Rosją nie wykluczały się, lecz dopełniały ${ }^{70}$. Jednocześnie rząd „,wielkiej koalicji” starał się, by współpraca bilateralna z Rosją w płaszczyźnie energetycznej i politycznej uwzględniała interesy partnerów z UE ${ }^{71}$. Jednym z najważniejszych celów, jaki postawiły przed sobą Niemcy w okresie swojej prezydencji w UE w pierwszej połowie 2007 roku było ułożenie stosunków z Rosją w taki sposób, aby zapewnić bezpieczne dostawy surowców energetycznych ${ }^{72}$.

Rząd niemiecki w miesiącach poprzedzających objęcie przez Niemcy z dniem 1 stycznia 2007 roku przewodnictwa w UE przygotował projekt pod kierunkiem ministra spraw zagranicznych, Franka Waltera Steinmeira, unijnej polityki wschodniej, w którym za priorytetowe uznano zbliżenie Rosji z Europą i zbliżenie Rosji z krajami Europy Środkowej ${ }^{73}$. W tym samym czasie niektórzy polscy politycy występowali

Kontynuacja i zmiana po zjednoczeniu ze szczególnym uwzględnieniem polityki europejskiej i transatlantyckiej, Warszawa 2005, s. 187 i n.; Ch. Meier, Die „, Grosse Koalition”...

68 Szerzej zob. E. Cziomer, Europejski wymiar polityki Niemiec wobec Rosji i Ukrainy oraz jej implikacje dla Polski, „Krakowskie Studia Międzynarodowe” 2009, nr 4(V), s. 165 i n.; B. Molo, Znaczenie Rosji dla bezpieczeństwa energetycznego Niemiec..., s. 240 i n.; R. Götz, Deutschland und Russland - , strategische Partner”?, „Aus Politik und Zeitgeschichte” 2006, nr 11; E. Cziomer, Międzynarodowe implikacje partnerstwa strategicznego Niemcy-Rosja...

${ }^{69}$ H. Zimmermann, Die deutsch-russischen Beziehungen..., s. 101 i n.

70 Jesteśmy siebie ciekawi. Rozmowa z paniq kanclerz Republiki Federalnej Niemiec Angela Merkel, ,Polityka” z 17 VI 2006.

${ }_{71}$ Ch. Meier, Deutsche Russlandpolitik zu Beginn des 21. Jahhunderts: Kontinuität un Wandel, „Krakowskie Studia Międzynarodowe” 2006, nr 4 (III).

${ }_{72}$ Ch. Hacke, Deutsche Aussenpolitik..., s. 34 i n.

73 Ibidem, s. 34 i n. Zob. H. D. Jacobsen, H. Machowski, Dimensionen einer neuen Ostpolitik der EU, „Aus Politik und Zeitgeschichte” 2007, Nr. 10. 
z propozycją, by Polska, Niemcy i USA wspólnie prowadziły konsultacje nad przyszłą polityką wschodnią UE wobec Rosji ${ }^{74}$. Zarówno w Niemczech, jak i w większości państw UE postulat współkształtowania przez USA unijnej polityki wschodniej cieszył się wówczas niewielkim poparciem.

Jak już zostało wspomniane, kluczową rolę w relacjach niemiecko-rosyjskich odgrywała współpraca w dziedzinie gospodarczej. Dla Rosji Niemcy były najważniejszym partnerem gospodarczym. Natomiast dla Niemiec wymiana handlowa z Rosją sytuowała ją w roku 2005 na 13-14 miejscu wśród partnerów gospodarczych ${ }^{75}$. O wiele ważniejsza była rola Rosji dla gospodarki niemieckiej jako importera podstawowych surowców energetycznych. W tym czasie ok. 34\% zapotrzebowania gospodarki niemieckiej na ropę naftową i $42 \%$ zapotrzebowania na gaz było pokrywane dostawami $\mathrm{z}_{\text {Rosji }}{ }^{76}$. Przewidywano, że do roku 2020 nastapi dalszy wzrost zapatrzenia Niemiec w dostawy rosyjskiej ropy naftowej do $42 \%$ i gazu do $55 \%$ lub nawet $60 \%{ }^{77}$. Bardzo skromne zasoby własne surowców energetycznych, a jednocześnie olbrzymie na nie zapotrzebowanie jednej z największych gospodarek świata sprawiały, że Niemcy zaliczane były do największych światowych importerów ropy i gazu. Wysokie zapotrzebowanie gospodarki niemieckiej na rosyjski gaz ziemny było głównym motywem zacieśniania współpracy z Rosją w dziedzinie dostaw surowców energetycznych. Najbardziej wyrazistym, a zarazem dla wielu bardzo kontrowersyjnym tego przykładem było podpisanie w obecności kanclerza RFN Gerharda Schrödera i prezydenta Rosji Władymira Putina w dniu 8 września 2005 roku porozumienia niemiecko-rosyjskiego w sprawie budowy gazociagu bałtyckiego (North Stream), którym z pominięciem terytorium Polski miał być dostarczany gaz z Syberii do Niemiec. Po stronie polskiej przedsięwzięcie to, wspierane w kolejnych latach przez coraz większą część państw UE, zostało ocenione jako znaczne pomniejszenie bezpieczeństwa energetycznego Polski (np. zwiększała się możliwość odcięcia Polsce dostaw gazu przez Rosję w sytuacji wzrostu politycznych napięć w relacjach polsko-rosyjskich $)^{78}$, odejście Niemiec od zasady solidarności w UE oraz bardzo poważne zagrożenie dla środowiska naturalnego Morza Bałtyckiego. Dla Niemiec gazociąg północny stanowi istotny wkład w osiągnięcie bezpieczeństwa

\footnotetext{
74 Jak politykować z Rosja. Wywiad przewodniczqcego Sejmowej Komisji Spraw Zagranicznych Pawła Zalewskiego, „Gazeta Wyborcza”, 5 X 2006.

75 W kolejnych latach wzrastały niemiecko-rosyjskie obroty handlowe. W roku 2008 wartość niemiecko-rosyjskiej wymiany handlowej szacowano na ponad 70 mld euro, z tego 33 mld euro stanowił niemiecki eksport do Rosji, a import, głównie gazu i ropy, sięgnął 37 mld euro. Za: E. Cziomer, Polityka zagraniczna Niemiec $w$ dobie nowych wyzwań globalizacji..., s. 222.

76 B. Koszel, Polska i Niemcy w Unii Europejskiej..., s. 172; E. Cziomer, Międzynarodowe bezpieczeństwo energetyczne Niemiec u progu XXI wieku, „Krakowskie Studia Międzynarodowe” 2007, nr 4(IV).

77 Ch. Meier, Deutsche Russlandpolitik zu Beginn des 21. Jahrhunders... s. 226.

$78 \mathrm{Z}$ chwilą wybudowania gazociagu bałtyckiego straci na znaczeniu gazociag, którym dostarczany jest rosyjski gaz do Polski. Pojawia się uzasadniona obawa, że w takiej sytuacji Polska będzie bardziej niż do tej pory narażona na gazowy szantaż ze strony Rosji. Polska znacznie by straciła w wymiarze politycznym i ekonomicznym w relacjach z Rosją, ale i z UE, z racji swojego tranzytowego położenia. Szerzej zob. R. M. Czarny, Gazociag Pótnocny a bezpieczeństwo energetyczne Polski ze szczególnym uwzględnieniem gazu ziemnego, „Krakowskie Studia Międzynarodowe” 2007, $\mathrm{nr} 4$ (IV); R. M. Czarny, Kontrowersje wokół Gazociagu Pótnocnego-implikacje dla państw regionu Morza Baltyckiego, „Krakowskie Studia Międzynarodowe” 2008, nr 4(V).
} 
energetycznego, ponieważ nie będzie przebiegał przez „niepewne” kraje tranzytowe (tzn. Ukrainę i Białoruś) ${ }^{79}$. Z punktu widzenia interesów Rosji gazociąg północny, którego pierwszą nitkę planowano ukończyć w roku 2012, stwarzał m.in. nowe możliwości przesyłu gazu ziemnego do Europy Zachodniej bez pośredniczenia państw trzecich, których polityczne napięcia z Rosją mogłyby prowadzić do zakłócenia w dostawach tego surowca do Niemiec, krajów Beneluksu, Wielkiej Brytanii i innych państw Europy Zachodniej. Gazociąg po dnie Bałtyku był traktowany przez rząd niemiecki jako europejski projekt energetyczny i ważny element dywersyfikacji dostaw gazu do Europy oraz jeden ze sposobów uniezależnienia się Niemiec od kopalnych nośników energii ${ }^{80}$.

W niemieckiej koncepcji bezpieczeństwa energetycznego Unii Europejskiej akcent kładziono na potrzebę kooperatywnego podejścia do tej problematyki, w którym zakładano bliską współpracę UE i Rosji ${ }^{81}$. Istotną rolę w takim podejściu odgrywało także duże zaangażowanie niemieckich przedsiębiorstw w rosyjskim sektorze energetycznym (np. EON Ruhrgas). Natomiast niektóre inicjatywy podejmowane w tym zakresie przez dyplomację polską zmierzały wręcz do wykluczenia Rosji z przedsięwzięć na rzecz wzmacniania bezpieczeństwa energetycznego państw członkowskich UE. Taki charakter miał zgłoszony przez premiera Kazimierza Marcinkiewicza na początku

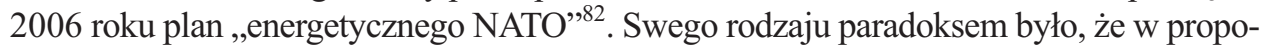
zycji tej ważną rolę wyznaczano Stanom Zjednoczonym z jednoczesnym wykluczeniem udziału Rosji, głównego eksportera surowców energetycznych dla państw członkowskich UE. W czasie, kiedy UE przygotowywała się do zawarcia nowego paktu energetycznego z Rosją, Polska proponowała rozwiązanie wykluczające Rosję. Nie mogło więc dziwić, że polski plan „energetycznego NATO” został bardzo chłodno przyjęty przez niemiecki rząd. Politycy niemieccy wyrażali również poważne wątpliwości na temat roli USA w tym systemie chociażby z tego względu, że postrzegały Stany Zjednoczone jako konkurenta na rynku energetycznym ${ }^{83}$.

W kolejnych latach wzrastał po stronie niemieckiej stopień akceptacji dla wspólnych inicjatyw UE w zakresie bezpieczeństwa energetycznego dotyczących bezpośrednio Rosji i do wypracowania kompromisu w ramach UE dotyczącego „solidarności energetycznej" w sytuacjach kryzysowych. Związane to było przede wszystkim z kolejnymi napięciami w relacjach Rosji z Białorusią i Ukrainą w latach 2006-2009 na tle podwyższanych przez Rosję cen ropy naftowej i gazu dla tych państw (w kierunku

79 R. Götz, Deutschland und Russland - , strategische Partner”?, „Aus Politik und Zeitgeschichte" 2006, Nr. 11, s. 14 i n.

80 Niemcy pamiętaja o ,, Solidarności”. Wywiad z Frankiem-Walterem Steinmeierem, ministrem spraw zagranicznych Niemiec, „Rzeczpospolita”, 9 II 2009. Zob. E. Cziomer, Niemcy a kwestia międzynarodowego bezpieczeństwa energetycznego, w: Międzynarodowe bezpieczeństwo energetyczne w XXI wieku...

${ }^{81}$ A. Guział, Miejsce Rosji w polityce zagranicznej RFN a szanse na wspólna politykę wschodnia UE, „Przegląd Zachodni” 2006, nr 2, s. 44; E. Cziomer, Niemcy a kwestia międzynarodowego bezpieczeństwa energetycznego...

82 K. Trębski, Plan Marcinkiewicza, „Wprost” z 5 II 200; B. Sienkiewicz, Czwarta RP w czwartej lidze, ,Newsweek” z 7 V 2006.

${ }^{83}$ A. Baring, Ignorancja polityków, „Europa” dodatek do „Dziennik. Polska. Europa. Świat” z 10 XI 2006; Ch. Hacke, Mehr Bismarck, weniger Habermas. Ein neuer Realismus in der deutschen Aussenpolitik?, „Internationale Politik” 2006, Nr. 6, s. 70. 
stopniowego ich zrównania z cenami światowymi) i egzekwowanie nowych cen nawet przez zamykanie dopływu na pewien czas tych surowców dla tych państw. W praktyce oznaczało to także poważne zakłócenia w dostawach ropy i gazu dla Polski, Niemiec i wielu innych państw członkowskich UE. Znacznie zmniejszyło się postrzeganie Rosji jako pewnego dostawcy nośników energii dla Niemiec. Rząd niemiecki zaangażował się w wiele kluczowych dla bezpieczeństwa energetycznego Unii inicjatyw, w tym wypracowanie przez Unię wspólnej polityki energetycznej i poparcie dla gazociągu Nabucco. Kanclerz A. Merkel zabiegała także o ratyfikowanie przez Rosję Europejskiej Karty Energetycznej. Jednakże zarówno jej, jak i innym politykom państw członkowskich UE nie udało się do tego nakłonić prezydenta Putina. Strona rosyjska nie była zainteresowana rozbudową instytucjonalnych powiązań z UE jako całością, preferując współpracę bilateralną i takież porozumienia - w pierwszej kolejności z Niemcami i pozostałymi największymi państwami UE. Ratyfikowanie przez Rosję Europejskiej Karty Energetycznej musiałoby też oznaczać większe otwarcie rosyjskiego rynku energetycznego dla koncernów zachodnich oraz urynkowienie cen ropy i gazu na rynku wewnętrznym Rosji, co w praktyce musiałoby oznaczać ich znaczny wzrost dla konsumentów rosyjskich. Grupy rządzące Rosji nie były skłonne do takich rozwiązań ${ }^{84}$.

Niemcy, mimo że poparły Polskę w jej sporze z Rosją w sprawie rosyjskiego embarga na eksport polskiego mięsa i jego przetworów do Rosji, jednak niezbyt przychylnie patrzyły na polskie weto w sprawie rozpoczęcia rozmów UE z Federacją Rosyjską na temat nowego układu o partnerstwie. Polskie weto burzyło niemiecką koncepcję dobrego ułożenia stosunków unijno-rosyjskich ${ }^{85}$. W listopadzie 2006 r. Polska domagając się uchylenia wprowadzonego w listopadzie 2005 r. przez Rosję embarga na dostawy polskiego mięsa na rynek rosyjski, zablokowała przygotowania do rozpoczęcia rokowań Unii z Rosją na temat nowego układu o współpracy i partnerstwie ${ }^{86}$. Polskie władze blokowały rozmowy, uzasadniając swoje poparcie od zniesienia nałożonych przez Rosję restrykcji. Po stronie unijnej dominowało przekonanie, że to nie poważne uchybienia sanitarne były przyczyną wprowadzenia przez Rosję na jesieni 2005 r. zakazu importu polskich produktów mięsnych, ale zaangażowanie polskich polityków w popieranie „pomarańczowej rewolucji” na Ukrainie oraz opowiadanie się rządu PiS za twardszą polityką UE wobec Rosji. Polskie weto wobec rozpoczęcia rozmów Rosja-Unia Europejska na temat nowego układu o współpracy i partnerstwie, wspierane mocno przez Litwę, wpłynęło także na brak poważniejszych wyników szczytu UE-Rosja, który odbył się 18 maja 2007 r. w Samarze. W polskiej prasie z satysfakcją przytaczano zapewnienia kanclerz A. Merkel, w czasie niemieckiej prezydencji w UE, że Unia będzie solidarna z Polską wobec rosyjskiego embarga na polskie mięso, a także krytyczne słowa niemieckiej kanclerz wypowiedziane pod adresem stanu rosyjskiej

${ }^{84}$ Zob. B. Molo, Polityka bezpieczeństwa energetycznego Federacji Rosyjskiej...

85 B. Koszel, Stosunki Polska-Niemcy a bezpieczeństwo europejskie, w: Polska-Niemcy 1945-2007. Od konfrontacji do wspólpracy i partnerstwa w Europie. Studia i dokumenty, red. W. M. Góralski, Warszawa 2007, s. 259.

${ }_{86}$ Strona rosyjska uzasadniała tę decyzję fałszowaniem polskich certyfikatów eksportowych. Faktycznie, u źródeł tej decyzji znajdowały się motywy polityczne, reakcja na zdecydowaną, bezkompromisową politykę rządu PiS wobec Rosji. 
demokracji ${ }^{87}$. Z tych samych względów brakiem uzgodnień w sprawie uzyskania mandatu dla rozpoczęcia rozmów z Rosją w sprawie nowego traktatu zakończyło się spotkanie na szczycie FR-UE w Mafrze w Portugalii (26 X 2007). Jednakże dyplomacja niemiecka wykazywała się determinacją w dążeniu do podpisania nowego układu UE-Rosja (dotychczasowy układ UE-Rosja z 1994 r. tracił swą ważność z dniem 1 stycznia 2008 r.), który miał potwierdzić partnerstwo strategiczne UE z Rosją ${ }^{88}$. Po decyzji władz Rosji o zniesienie z początkiem 2008 r. embarga na polskie mięso rząd Polski odstapił od blokowania rozmów w sprawie nowego traktatu unijno-rosyjskiego. Pozwoliło to na podjęcie decyzji w czasie szczytu UE-Rosja w Chanty-Mansijsku (27 VI 2008) o rozpoczęciu negocjacji w sprawie nowego traktatu UE-FR, dotyczącego podstaw wzajemnych stosunków. Dyskusja na następnym szczycie UE-Rosja, który odbył się w Nicei (14 XI 2008) zdominowana została przez problemy dotyczące światowego kryzysu finansowego oraz sytuacji w Gruzji po konflikcie gruzińsko-rosyjsko-osetyńskim w sierpniu 2008 roku. Problemy związane z kryzysem finansowo-gospodarczym zdominowały politykę wewnętrzną i zagraniczną Niemiec, podobnie jak wielu innych państw, także w roku 2009.

W wyniku wyborów do Bundestagu 27 września 2009 r. utworzona została w Niemczech nowa koalicja rządząca złożona z partii chadeckich CDU/CSU oraz partii liberalnej FDP. Funkcję kanclerza ponownie objęła Angela Merkel, a wicekanclerzem i ministrem spraw zagranicznych został Guido Westerwelle. W polityce zagranicznej nowa koalicja deklarowała kontynuację głównych celów i kierunków aktywności Niemiec na arenie międzynarodowej. Chociaż w układzie koalicyjnym rządu CDU/CSU/FDP z 26 października 2009 r. nie postrzegano Rosji jako partnera strategicznego, lecz jako „ważnego partnera", to w kolejnych miesiącach politycy niemieccy, w tym minister G. Westerwelle, powrócili do określania stosunków niemiecko-rosyjskich w kategoriach strategicznego partnerstwa ${ }^{89}$.

\section{Polska wobec polityki wschodniej UE i stosunków z Rosją}

W okresie stowarzyszenia Polski z WE/UE zainteresowanie Polski Wspólną Polityką Zagraniczną i Bezpieczeństwa sprowadzało się w zasadzie do ograniczonych konsultacji politycznych z państwami członkowskimi UE w tym obszarze ${ }^{90}$. W czasie negocjacji akcesyjnych Polski z UE rozdział 27 poświęcony WPZiB był jednym z najłatwiejszych. W przedłożonym 1 września 1999 roku stanowisku negocjacyjnym w obszarze WPZiB Polska nie występowała o żadne okresy przejściowe. W stanowisku

\footnotetext{
87 A. Talaga, Merkel oferuje partnerstwo, „Dziennik”, 18 III 2007; J. Kumoch, Nowa Unia nie polubi Putina, „Dziennik”, 18 V 2007.

88 E. Cziomer, Europejski wymiar polityki Niemiec wobec Rosji i Ukrainy oraz jej implikacje dla Polski, „Krakowskie Studia Międzynarodowe” 2009, nr 4(V), s. 167.

89 E. Cziomer, Polityka zagraniczna Niemiec w dobie nowych wyzwań globalizacji, bezpieczeństwa międzynarodowego oraz integracji europejskiej po 2005 roku, Warszawa-Kraków 2010, s. 216 i n.

90 T. Łoś-Nowak, Stanowisko Polski wobec Wspólnej Polityki Zagranicznej i Bezpieczeństwa Unii Europejskiej, w: Międzynarodowe implikacje procesu integracji europejskiej dla Polski i Niemiec, red. E. Cziomer, M. Czajkowski, Kraków 2004, s. 122-123.
} 
tym wyrażone zostały m.in. przekonanie o istnieniu zasadniczej zbieżności polskiej polityki zagranicznej ze WPZiB UE, potwierdzenie gotowości Polski do aktywnego udziału we współpracy w ramach WPZiB oraz wola uczestniczenia w kształtowaniu wschodniego wymiaru polityki UE. Po krótkich rokowaniach już 6 kwietnia 2000 roku uznano ten rozdział za (tymczasowo) zamknięty. Po zakończeniu negocjacji akcesyjnych z UE wpływ Polski na wypracowanie nowych zasad współpracy w ramach WPZiB przejawiał się przede wszystkim w udziale polskich przedstawicieli w pracach Konwentu Europejskiego, a w jeszcze większym stopniu - w udziale przedstawicieli polskiego rządu w konferencji międzyrządowej, która zajęła się wypracowywaniem ostatecznej wersji Traktatu Konstytucyjnego, także postanowień dotyczących bezpośrednio WPZiB oraz WPBiO. W tym samym czasie Polska angażowała się w przedsięwzięcia, które pod znakiem zapytania stawiały WPZiB UE (np. tzw. list ośmiu, z podpisem premiera polskiego rządu oraz udział Polski w interwencji militarnej w Iraku) ${ }^{91}$.

Z chwilą wejścia Polski do Unii Europejskiej kwestie związane z WPZiB i EPBiO stanowiły niezwykle istotny element polskiej polityki zagranicznej i polskiej polityki bezpieczeństwa. Po 1 maja 2004 roku Polska uzyskała realny wpływ na kształt polityki zagranicznej i bezpieczeństwa oraz polityki obrony Unii Europejskiej, w tym na stopień rozwiązania głównych problemów tej sfery integracji. Jedną z cech najbardziej charakterystycznych stanowiska Polski wobec zgłaszanych w kolejnych latach propozycji reform WPZiB oraz EPBiO było zabieganie o utrzymanie międzyrządowego charakteru współpracy w tym obszarze ${ }^{92}$. Polska opowiadała się zdecydowanie za utrzymaniem zasady jednomyślności $\mathrm{w}$ mechanizmie podejmowania decyzji w ramach WPZiB przez Radę Europejską i Radę Unii Europejskiej (Radę Ministrów). Sceptycznie podchodziła do prób powołania Ministra Spraw Zagranicznych Unii Europejskiej i Europejskiej Służby Działań Zewnętrznych. Przedstawiciele polskich rządów szczególnie dystansowali się od rozwijania polityki obronnej UE, w tym - jej instytucjonalizacji, upatrując w tym zagrożenie dla spoistości NATO i obecności wojskowej USA w Europie $^{93}$. Wówczas Niemcy należały do głównych zwolenników zarówno wzmocnienia współpracy w ramach WPZiB i jej instytucjonalizacji, jak i rozszerzenia współpracy unijnej na kwestie wojskowe i obronne, opowiadając się np. za współpracą strukturalną w ramach powołanej przez Traktat Konstytucyjny Wspólnej Polityki Bezpieczeństwa i Obrony (w miejsce EPBiO). Założenia te znalazły także swój wyraz w podpisanym 13 grudnia 2007 roku Traktacie z Lizbony, który wszedł w życie z dniem 1 grudnia 2009 roku.

91 Zob. M. Stolarczyk, Kontrowersje wokót militarnego zaangażowania Polski w Iraku, „Studia Politicae Universitatis Silesiensis" 2005, nr 1.

92 Marcin Libicki, poseł do Parlamentu Europejskiego z listy PiS pisał, że nadal spod kompetencji Unii powinna być wyłączona polityka zagraniczna. „W przyszłości chętnie widzielibyśmy Unię gwarantującą swoją wspólną politykę zagraniczną, bezpieczeństwo międzynarodowe oraz odpowiednią reprezentację polskich interesów. Dziś jednak i w najbliższej przyszłości taka integracja wiązałaby się z ogromnym ryzykiem prowadzenia wspólnej polityki zagranicznej pod dyktando największych państw UE”. M. Libicki, Unia zmiennych sojuszy, „Gazeta Wyborcza” 3 II 2006.

${ }^{3}$ Zob. J. Zając, Wspólna Polityka Zagraniczna i Bezpieczeństwa Unii Europejskiej jako wyzwanie dla Polski, w: Unia Europejska i Polska wobec dylematów integracyjnych na poczatku XXI wieku, red. M. Stolarczyk, Toruń 2006. 
Polska uczestnicząc w współkształtowaniu WPZiB, zainteresowana była, głównie ze względu na geopolityczne i historyczne doświadczenia, przede wszystkim wschodnim wymiarem WPZiB Unii Europejskiej. W zdecydowanie mniejszym stopniu angażowała się w kształtowanie i rozwój innych kierunków unijnej polityki zagranicznej i bezpieczeństwa. Polska wraz z uzyskaniem członkostwa w UE aspirowała do roli nie tylko dobrego adwokata integracji z UE naszych wschodnich sąsiadów, ale także głównego architekta wymiaru wschodniego Unii Europejskiej (unijnej polityki wschodniej). Przedstawiciele kolejnych polskich rządów podkreślali, że Polska ze względu na swoje sąsiedztwo jest szczególnie zainteresowana, by jako państwo członkowskie Unii uczestniczyć w kształtowaniu jej polityki wschodniej, by przyjąć szczególną odpowiedzialność za rozwój aktywnych stosunków z sąsiadami na wschodzie, a przede wszystkim z Ukrainą. Deklarowali gotowość na rzecz stworzenia i rozwijania wschodniego wymiaru UE. Tendencja ta wzmocniona została po sukcesie polskiej dyplomacji, która zdołała przekonać UE do swoich poglądów w czasie „,pomarańczowej rewolucji” na Ukrainie pod koniec 2004 roku. Efektywna polityka wschodnia UE, kształtowana w dużej mierze przez Polskę, była postrzegana przez polskie elity polityczne jako skuteczny instrument przeciwdziałania niekorzystnym dla polskich interesów działaniom ze strony Rosji. Politycy polscy prezentowali stanowisko, że rozumieją sytuację na obszarze byłego Związku Radzieckiego, w tym rzeczywistość rosyjska, lepiej niż elity polityczne na Zachodzie. Minister spraw zagranicznych Polski, Radosław Sikorski, w wystąpieniu na forum Sejmu w maju 2008 roku stwierdził m.in., że ,aktywność w odniesieniu do kierunku wschodniego unijnej polityki zagranicznej powinna pozostać polską specjalnością"94. Pojawiały się też opinie, że Polska powinna być zainteresowana jednolitą polityką zagraniczną UE, bo to zabezpiecza nasz kraj przed powstaniem nowej osi: Berlin-Moskwa czy nadmiernym wzmocnieniem trójkąta: Rosja-Niemcy-Francja (tzw. europejskiej trojki). Jednocześnie nie zawsze zdawano sobie sprawę z tego, że bez wsparcia RFN nie będzie możliwa realizacja polskiego projektu polskiej polityki wschodniej UE ${ }^{95}$.

W tym samym czasie między polską i niemiecką wizją polityki wschodniej UE, szczególnie wobec Rosji i Ukrainy, występowały poważne różnice. Polska klasa polityczna, w przeciwieństwie do niemieckiej, postrzegała zazwyczaj Rosję jako zagrożenie, a nie jako partnera. Polskie elity polityczne Rosję traktowały zazwyczaj jako prostą kontynuację imperium radzieckiego, egzystencjalnego wroga o ponadczasowym charakterze $^{96}$. Z tych m.in. względów zarówno Niemcy, jak i pozostałe państwa członkowskie nie dawały przyzwolenia na to, by Polska „odpowiadała” za Rosję w Unii Europejskiej. Dieter Bingen pisał, że w Niemczech zasadniczo nie docenia się istniejącej w Polsce historycznej i naukowej kompetencji w odniesieniu do wschodnich

94 Informacja polskiego ministra spraw zagranicznych Radosława Sikorskiego na temat polityki zagranicznej RP w 2008 roku, w: K. Łastawski, Polska racja stanu po wstapieniu do Unii Europejskiej, Warszawa 2009, s. 227.

95 Zob. M. Fałkowski, K.-O. Lang, Wspólne zadanie. Polska, Niemcy i Ukraina w przeobrażajacej się Europie, Warszawa 2004.

96 S. Bieleń, Stosunki Unia Europejska-Rosja, w: Dyplomacja czy siła?..., s. 233. Zob. M. Stolarczyk, Rola Rosji w polityce bezpieczeństwa Polski pod koniec pierwszej dekady XXI w., w: Polska wobec wyzwań bezpieczeństwa narodowego, red. K. Budzowski, Kraków 2010. 
sąsiadów, jak również możliwego wkładu Polski w aktywną politykę wschodnią Unii Europejskiej $^{97}$. Także niektórzy polscy analitycy spraw międzynarodowych zauważali, że polska polityka wschodnia wywołuje w Unii rozdrażnienie. Wskazywali, że jeśli Polska chce kreować europejską politykę wschodnią, to polskie elity nie mogą wypowiadać się w sposób, który nadaje im piętno rusofobów ${ }^{98}$.

Przystąpienie Polski do NATO i Unii Europejskiej, wbrew niektórym prognozom, nie zaowocowało lepszymi stosunkami Polski z Rosją 99 . Mimo nadziei na otwarcie nowego etapu, w pierwszej dekadzie XXI wieku w relacjach polsko-rosyjskich nie doszło do ,pożegnania z nieufnością"100. Polityczne stosunki polsko-rosyjskie nadal znajdowały się w kryzysie. Do głównych problemów spornych należały: rozbieżne stanowiska dotyczące oceny historii; kolejne etapy rozszerzania NATO i popieranie przez Polskę dążeń niektórych państw obszaru poradzieckiego do członkostwa w NATO (m.in. Ukrainy i Gruzji); duży stopień zaangażowania Polski w działania na rzecz budowy podstaw demokracji na Ukrainie i Białorusi; krytyczną ocenę Polski wykorzystywania przez Rosję eksportu gazu i ropy do realizacji celów politycznych; rosyjskie utrudnienia w dostępie polskiej żywności na rynek rosyjski; polską krytykę rosyjskich działań militarnych w Czeczenii i w Gruzji ${ }^{101}$. Charakter stosunków polsko-rosyjskich w owym czasie określany był niekiedy terminem ,inercyjne współistnienie"102 .

Jedną z cech najbardziej charakterystycznych stosunków polsko-rosyjskich w okresie pozimnowojennym było to, że obie strony patrzyły na siebie przez pryzmat historii. Ciążenie historii (pamięć historyczna) w stosunkach polsko-rosyjskich było większe niż w relacjach polsko-niemieckich. Na początku XXI wieku w społeczeństwie pol-

97 D. Bingen, Niemcy, Polacy i ich squsiedzi na wschodzie. Nowe wyzwania, w: Polacy - Niemcy. Sasiedztwo z dystansu, red. A. Wolf-Powęska, D. Bingen, Warszawa 2004, s. 211.

98 A. Podolski, Polityka wschodnia czy antyrosyjska?, „Gazeta Wyborcza” z 30 XI 2004. Zob. S. Bieleń, Paradoksy polskiej polityki zagranicznej, „Studia Europejskie” 2004, nr 2, s. 20.

99 W ocenie Zbigniewa Brzezińskiego członkostwo Polski w NATO miało stworzyć możliwości dla powolnego, ale konsekwentnego pojednania polsko-rosyjskiego. Przez ostatnie stulecia - mówił Zbigniew Brzeziński - pojednanie polsko-rosyjskie ,nie było możliwe, gdyż sytuacja nie dawała Polsce wielkiego wyboru: albo być wasalem Rosji, albo Rosję zwalczać. Dziś ani jedno, ani drugie nie wchodzi w rachubę. Polska nie potrzebuje Rosji zwalczać, gdyż pozyskała nowy wymiar bezpieczeństwa i nowe możliwości euroatlantyckie. A Rosja nie ma najmniejszej szansy dominowania nad Polską”. Wschodni filar. Rozmowa ze Zbigniewem Brzezińskim, „Polityka” 1999, nr 11. Natomiast Friedbert Pflüger, członek frakcji CDU/CSU w niemieckim Bundestagu, pisał, że członkostwo Polski w NATO nie jest przeszkodą, lecz niezbędnym warunkiem pojednania polsko-rosyjskiego. Tylko ten bowiem, kto czuje się bezpiecznie, może podtrzymywać partnerskie więzi i rozwijać współpracę. F. Pflüger, Warunek pojednania Polski z Rosja, „Dialog” 1998, nr 2, s. 104. Wbrew tym prognozom, w kolejnych latach po wejściu Polski do NATO, coraz ściślejszym związkom polsko-amerykańskim towarzyszyło pogorszenie relacji polsko-rosyjskich.

100 E. Stadtmüller, Pożegnanie z nieufnościa. Rozszerzenie NATO i UE a stosunki polsko-rosyjskie w kontekście bezpieczeństwa europejskiego, Wrocław 2003.

101 Szerzej zob. Skomplikowane stosunki Polaków i Rosjan, red. M. Dobroczyński, J. Marszałek-Kawa, Toruń 2005; Polska i Rosja. Strategiczne sprzeczności i możliwości dialogu, red. A. Magdziak-Miszewska, Warszawa 1998; Polacy i Rosjanie. Czynniki zbliżenia, red. M. Dobraczyński, Warszawa-Toruń 1998; A. Grajewski, Wyzwania polskiej polityki wschodniej, w: Polityka zagraniczna Polski. Unia Europejska, Stany Zjednoczone, Sasiedzi, red. J. Czaputowicz, Warszawa 2008.

102 J. J. Mizgała, Cele polityki rosyjskiej wobec Polski, w: Polityka zagraniczna Polski. Unia Europejska, Stany Zjednoczone... 
skim zdecydowanie więcej było resentymentów antyrosyjskich niż antyniemieckich. Wiele kluczowych wydarzeń w historii obu narodów interpretowanych było z symetryczną odmiennością przez każdą ze stron (np. oceny roli ZSRR w latach II wojny światowej i po jej zakończeniu). Pamięć historyczna Polaków i Rosjan była krańcowo różna i zapewne wspólnej wizji historii nie będzie także w przyszłości. Podzielić należy pogląd, że spory o interpretację historii mogą toczyć się nie tylko przez lata, lecz również przez stulecia ${ }^{103}$. Jednakże to przede wszystkim od grup rządzących obu państw zależało w jakim stopniu spory historyczne będą obciążeniem dla bieżących relacji międzyrządowych Polski i Rosji. Rosja jest i zapewne pozostanie głównym partnerem gospodarczym Polski na wschodzie ${ }^{104}$, w tym przede wszystkim głównym dostawcą surowców strategicznych dla polskiej gospodarki. Na początku XXI wieku około $90 \%$ zapotrzebowania polskiej gospodarki na ropę naftową i ok. 60\% zapotrzebowania na gaz pokrywane było importem z Rosji. Mimo wysiłków podejmowanych w Polsce na rzecz dywersyfikacji dostaw tych surowców z innych państw Rosja najprawdopodobniej nie przestanie być ich głównym dostawcą dla polskiej gospodarki. Wbrew jednak wskaźnikom zależności importowej to nie ropa naftowa, a gaz ziemny był większym wyzwaniem dla bezpieczeństwa energetycznego Polski. W przypadku ropy Polska dysponowała trzema możliwościami importu: systemem rurociagowym „Drużba”, transportem morskim przez Port Północny w Gdańsku oraz transportem kolejowym. Natomiast w przypadku gazu ziemnego, ze względu na istniejącą sieć gazową, Polska nie miała takiej swobody wyboru zewnętrznego dostawcy ${ }^{105}$. $\mathrm{Z}$ tych chociażby tylko względów, jak i polsko-rosyjskiego sąsiedztwa oraz roli mocarstwowej odgrywanej przez Rosję w stosunkach międzynarodowych, warto było podejmować wysiłki prowadzące do poprawy stosunków polsko-rosyjskich. Poprawa stosunków z Rosją była ważna dla naszego kraju zarówno z punktu widzenia interesów ekonomicznych, jak i długofalowych interesów bezpieczeństwa. Spory na tle historycznym oraz bardzo poważne różnice interesów w płaszczyźnie politycznej, bezpieczeństwa i ekonomicznej sprawiały, że w dającej się przewidzieć perspektywie mało realny był scenariusz, by relacje polsko-rosyjskie były równie dobre jak stosunki rosyjsko-niemieckie.

103 Anna Wolff-Powęska w dyskusji nad ,,polityką historyczną” zwracała uwagę na to, iż posługujemy się historią w sposób antagonizujący nasze stosunki i z Niemcami, i z Rosją. Powiedziała również: „dzisiaj tak mocno podkreślamy, że pragniemy promować naszą historię i naszą interpretację historii u sąsiadów. Musimy jednak liczyć się z tym, że oni także mogą oczekiwać wysłuchania przez Polaków ich historii. Jak znaleźć punkt styczny, wspólny mianownik tych tak różnych narracji?". A. Wolff-Powęska, Pamięć i przestrzeń publiczna, w: Pamięć i polityka zagraniczna, red. P. Kosiewski, Warszawa 2006, s. 120.

104 W roku 2008 wartość polskiego eksportu do Rosji wynosiła blisko 9 mld dol. a wartość importu z Rosji ponad 20,5 mld dol. Tym samym udział Rosji w polskim eksporcie wynosił 5,3\% a w imporcie 9,9\%. B. Cichocki, Polityka Polski wobec Rosji, „Rocznik Polskiej Polityki Zagranicznej 2009”, Warszawa 2009, s. 124. W roku 2008 Rosja zajmowała drugie miejsce wśród głównych polskich importerów i szóste miejsce wśród największych polskich eksporterów. A. Gradziuk, Stosunki gospodarcze Polski z zagranica, „,Rocznik Polskiej Polityki Zagranicznej 2009”, Warszawa 2009, s. 291.

105 K. Pronińska, Strategie bezpieczeństwa energetycznego..., s. 285. Zob. M. Lasoń, Polska wobec wyzwań bezpieczeństwa energetycznego, w: Międzynarodowe bezpieczeństwo energetyczne w XXI wieku ... W roku 2010 zwiększyły się nadzieje na wzmocnienie bezpieczeństwa energetycznego Polski w związku z odkryciem na terenie naszego kraju bogatych złóż gazu łupkowego. 
Faktem było, że Polska dynamizując swoją politykę wschodnią i angażując się na rzecz europeizacji Europy Wschodniej, nazbyt często czyniła to przeciwko Rosji. Uzyskany wraz z wejściem do NATO i UE wzrost poczucia bezpieczeństwa i związana z tym większa pewność siebie polskich elit politycznych na kierunku wschodnim nie została wykorzystana do zdecydowanej poprawy polsko-rosyjskich stosunków politycznych. Oczywiście, znaczna poprawa tych relacji tylko w części zależała od strony polskiej. Jednakże silne postawy nieukrywanej niechęci wobec Rosji czy wręcz rusofobia w społeczeństwie polskim, $w$ tym przede wszystkim w środkach masowego przekazu oraz wśród znacznej części polskich elit politycznych, raczej nie były atutem, lecz balastem dla relacji NATO-Rosja i UE-Rosja. Po wejściu Polski do NATO i UE napięcia w relacjach Polska-Rosja stały się zarazem problemem stosunków NATO-Rosja i UE-Rosja. Kraje NATO, a tym bardziej UE, nie były zainteresowane antagonizowaniem stosunków z Rosją, wręcz odwrotnie - chciały dalszego rozwoju współpracy. Pojawiały się sugestie, by członkostwo w NATO i UE Polska wykorzystywała do poprawy stosunków z Rosją, a nie do ich zaostrzania. Trafne było stwierdzenie Adama Michnika, że „kultywowanie fobii antyrosyjskich jest i niegodne, i sprzeczne z polską racją stanu" ${ }^{106}$. Z trudem zdobywał sobie aprobatę w naszym kraju pogląd, że rola Polski w strukturach europejskich i euroatlantyckich w znacznym stopniu jest determinowana stanem relacji polsko-rosyjskich ${ }^{107}$, a poprawie stosunków polsko-rosyjskich sprzyja rozwój stosunków z Niemcami. Politycy polscy deklarowali, że chcą poprawy stosunków z Rosją, ale to nie zależy od Polski tylko od Rosji, w tym od stopnia jej demokratyzacji. Wówczas też bardzo mocno angażowali się w amerykańską politykę pomniejszania wpływów rosyjskich na obszarze poradzieckim m.in. przez wspieranie tzw. kolorowych rewolucji (Gruzja, Ukraina). Nie zawsze zdawali się przy tym pamiętać o tym, że w relacjach z naszymi wschodnimi sąsiadami granica między wsparciem korzystnych dla nas tendencji a zaangażowaniem się w wewnętrzne sprawy jest szczególnie delikatna. Obciążanie za zły stan stosunków polsko-rosyjskich tylko strony rosyjskiej wydawało się oceną nazbyt jednostronną. Nie zauważano własnych błędów zarówno w polityce wewnętrznej (np. w prowadzonej polityce historycznej) i zagranicznej skutkujących pogorszeniem relacji polsko-rosyjskich. Decydenci polskiej polityki zagranicznej, niezależnie od opcji politycznych, wydawali się nie dostrzegać tego, że wiele podejmowanych przez nich działań, szczególnie w polskiej polityce wschodniej, było odbieranych przez grupy rządzące w Rosji jako niekorzystne z punktu widzenia interesów tego kraju. Politykę Polski wobec Rosji cechował wyraźny brak empatii. Politycy rosyjscy niekiedy stawiali pytanie: Dlaczego Rosja ma okazywać dobrą wolę wobec Polski, kraju, który zachowuje się wobec Rosji jak nieprzyjaciel? ${ }^{108}$ Dla niektórych obserwatorów polskiej polityki zagranicznej nasuwał się wniosek, że polska dyplomacja powinna z większą skutecznością rozpoznawać długofalowe i wieloaspek-

\footnotetext{
106 A. Michnik, Jak partnerzy, „Gazeta Wyborcza” z 22 XI 2000.

107 Były minister spraw zagranicznych Polski, Stefan Meller, pisał, że nasze miejsce w Europie, nasza rola w Unii Europejskiej zależą w znacznym stopniu od sposobu, w jaki ułożymy sobie stosunki z Rosją. S. Meller, Jak rozmawiać z Rosja, „Polski Przegląd Dyplomatyczny” 2008, nr 1, s. 27.

108 Zob. wywiad z Siergiejem Markowem, doradcą prezydenta Rosji W. Putina. „Europa” dodatek do: „Dziennik. Polska - Europa - Świat” z 17.022007.
} 
towe skutki swoich działań, które traktowane są przez stronę rosyjskąjako lekceważenie jej interesów. Przykładowo, nazbyt ostentacyjne zaangażowanie się polskich polityków w poparcie ukraińskiej ,,pomarańczowej rewolucji” i prezentowanie niekiedy tego zaangażowania jako działania u boku Stanów Zjednoczonych ${ }^{109}$, musiało się spotkać z negatywną oceną grup rządzących Rosji.

W przeciwieństwie do rządu polskiego, rząd niemiecki z pewnym ociaganiem opowiedział się po stronie ,pomarańczowej rewolucji”. Rząd niemiecki, w przeciwieństwie do większości niemieckich parlamentarzystów i niemieckich mediów, wykazywał wobec kryzysu politycznego na Ukrainie jesienią 2004 roku daleko posuniętą powściagliwość, co wynikało m.in. z dążenia do uwzględniania interesów rosyjskich i z niewiary w trwałość prozachodniego kursu w polityce Ukrainy, a także obaw związanych z implikacjami szybkiego przyjęcia Ukrainy do NATO i UE ${ }^{110}$. Kanclerz Schröder z pewnym opóźnieniem zaangażował się $\mathrm{w}$ proces stabilizacji sytuacji na Ukrainie na przełomie 2004 i 2005 roku. Nastapiło to m.in. w wyniku oddziaływań polskich polityków ${ }^{111}$. Uważa się, że po telefonicznych rozmowach kanclerza Schrödera z prezydentem Putinem strona rosyjska wzmocniła naciski na prorosyjską Partię Regionów i jej lidera Wiktora Janukowycza, które wpłynęły na opanowanie sytuacji kryzysowej na Ukrainie. Rząd niemiecki poparł także działania prezydenta Polski, Aleksandra Kwaśniewskiego, prezydenta Litwy, Valdasa Adamusa, oraz Wysokiego Przedstawiciela UE ds. WPZiB, Javiera Solany, którym w rozmowie z głównymi stronami konfliktu na Ukrainie udało się doprowadzić do porozumienia w sprawie powtórzenia wyborów prezydenckich na Ukrainie ${ }^{112}$. Zdecydowane poparcie przez Polskę ,pomarańczowej rewolucji" i zaangażowanie się polskiej dyplomacji w pokojowe rozwiązanie konfliktu na Ukrainie jesienią 2004 roku zazwyczaj oceniano jako ważny sukces polskiej polityki wschodniej. Jednakże faktem było, że bardzo duże zaangażowanie polskich polityków w czasie „rewolucji pomarańczowej” na Ukrainie wpłynęło jednocześnie na znacznie schłodzenie relacji polsko-rosyjskich. Grupy rządzące Rosji zinterpretowały tak zdecydowane zaangażowanie Polski w poparcie „pomarańczowej rewolucji” jako daleko idącą ingerencję w sprawy wewnętrzne Ukrainy i wzmacnianie ugrupowań ukraińskich nieprzychylnych Rosji. Administracja prezydenta Putina krytycznie oceniała nie tyle sam fakt poparcia przez Polskę zwolenników „,pomarańczowej rewolucji” (poparcie takie deklarowało bardzo wiele państw), ile przede wszystkim skalę polskiego zaangażowania we wspieraniu prozachodnich ugrupowań na Ukrainie na przełomie 2004 i 2005 roku. Rozwój wydarzeń na Ukrainie w kolejnych latach po roku 2004 wykazał, że politycy polscy nazbyt optymistycznie ocenili liderów „pomarańczowej rewolucji" $i$ ich dążenie do reformowania kraju i zbliżenia Ukrainy do struktur zachodnich. Rozczarowanie polityką liderów „pomarańczowej rewolucji” było jednym

109 W czasie trwania „pomarańczowej rewolucji” prezydent Polski Aleksander Kwaśniewski oświadczył, że dla każdego wielkiego mocarstwa Rosja jest lepsza bez Ukrainy, co po stronie rosyjskiej zostało zinterpretowane jako działanie Polski w imieniu Stanów Zjednoczonych.

${ }^{110}$ Na temat uwarunkowań i celów polityki Polski i Niemiec wobec Ukrainy zob. M. Fałkowski, K.-O. Lang, Wspólne zadanie. Polska, Niemcy i Ukraina...

111 E. Cziomer, Europejski wymiar polityki Niemiec..., s. 171-172.

112 W powtórzonych wyborach prezydenckich 26 grudnia 2004 r. zwyciężył jeden z liderów „pomarańczowej rewolucji” Wiktor Juszczenko. 
z czynników ewolucji polskiej polityki wschodniej pod koniec pierwszej dekady XXI w. w tym prowadzenie bardziej pragmatycznej polityki Polski wobec Ukrainy.

Znaczne różnice wystapiły także między polskimi i zachodnioeuropejskimi reakcjami, w tym niemieckimi ${ }^{113}$, na konflikt rosyjsko-gruziński w sierpniu 2008 roku. Jak już wspomniano, wielu polityków europejskich oceniało użycie przez Rosję siły militarnej wobec Gruzji jako uzasadnione, ale zbyt daleko idące i niewspółmierne do zagrożenia jej interesów. Takie stanowisko wynikało m.in. z przekonania, że stroną, która rozpoczęła pięciodniową wojnę na Kaukazie była Gruzja, a osobą najbardziej odpowiedzialną za wywołanie konfliktu zbrojnego był prezydent Gruzji, Micheil Saakaszwili. Odmienne stanowisko $w$ tej sprawie zajmowali politycy polscy i zdecydowana większość polskich mediów oraz polskiego społeczeństwa. Dominowało stanowisko zdecydowanego potępienia Rosji i bezkrytycznego podejścia do polityki prowadzonej przez Micheila Saakaszwilego. Działania militarne Rosji wobec Gruzji w sierpniu 2008 roku oceniane były w Polsce jako klasyczny akt agresji i bardzo ważny krok na drodze realizacji imperialnych dążeń Rosji, za którymi mogą pójść następne w postaci aneksji Ukrainy czy nawet Polski. Należy jednak zaznaczyć, że mimo jednoznacznie krytycznej oceny działań Rosji, w reakcjach głównych decydentów polskiej polityki zagranicznej na konflikt kaukaski w sierpniu 2008 roku występowała istotna różnica. Odmienne były inicjatywy z tym związane podejmowane przez polski rząd oraz reakcje i działania podejmowane przez prezydenta L. Kaczyńskiego ${ }^{114}$. Rząd premiera D. Tuska prezentował stanowisko bardziej wyważone, w ramach którego wspierał i pozytywnie oceniał rolę, jaką w zakończeniu głównej fazy tego konfliktu odegrała dyplomacja unijna, w tym prezydent Francji, Nicolas Sarkozy, który przewodnicząc wówczas Radzie Europejskiej, wynegocjował 12 sierpnia z prezydentem Rosji, Dmitijem Miedwiediewem, podstawy porozumienia pokojowego w sprawie Gruzji. Natomiast w reakcjach prezydenta L. Kaczyńskiego dominowała konfrontacyjna wobec Rosji retoryka. Górę wzięły emocje nad chłodna, wymaganą od głowy państwa, oceną tego rodzaju sytuacji. Przykładem tej nazbyt emocjonalnej postawy była zainspirowana przez polskiego prezydenta wizyta prezydentów Polski, Litwy, Estonii i Ukrainy oraz premiera Łotwy w stolicy Gruzji w dniu 12 sierpnia 2008 roku, podczas której na wiecu w Tbilisi Lech Kaczyński zapewniał Gruzinów: „[...] jesteśmy tu po to, żeby podjąć walkę"115. Stanowisko prezydenta Kaczyńskiego w sprawie konfliktu rosyjsko-gruzińskiego charakteryzowało się skrajną jednostronnością i brakiem jakichkolwiek elementów krytycznych wobec działań prezydenta Gruzji, Saakaszwilego, który rozpoczął ten konflikt przez wydanie rozkazu zbrojnego ataku w dniu 7 sierpnia 2008 roku na Cchinwali, stolicę Osetii Południowej ${ }^{116}$. Konfrontacyjna retoryka polskiego prezydenta nie zyskała poparcia $\mathrm{w}$ większości państw europejskich, które nie były zainteresowane długotrwałym pogorszeniem stosunków z Rosją.

113 N. Kohtamäki, Niemcy wobec konfliktu rosyjsko-gruzińskiego, „Biuletyn PISM”, Warszawa 2008, nr 44.

114 B. Cichocki, Polityka Polski wobec Rosji, ,Rocznik Polskiej Polityki zagranicznej 2009”, Warszawa 2009, s. 119; Ł. Kulesa, Polityka Polski wobec konfliktu gruzińskiego, ,Rocznik Polskiej Polityki Zagranicznej 2009", Warszawa 2009.

$115 \mathrm{http} / /$ wiadomosci.gazeta.pl/Wiadomsci/1,80708,5581803.

116 „Rocznik Strategiczny 2008/09”, Warszawa 2009, s. 76-77. 
Tylko nieliczni polscy analitycy starali się nie ulec antyrosyjskiej histerii, jaka miała miejsce w Polsce w sierpniu 2008 roku i w tygodniach następnych. Roman Kuźniar pisał, że konflikt na Kaukazie był klasycznym konfliktem ograniczonym. Na gruziński atak zbrojny na Osetię Południową Rosja odpowiedziała bardzo mocnym uderzeniem, którego cele były ściśle zdefiniowane (m.in. utrzymanie terytorialnego status quo, zniszczenie potencjału militarnego Gruzji, demonstracja siły przed innymi krajami Kaukazu i Azji Środkowej, zademonstrowanie siły w doktrynie powstrzymywania USA przed wzrostem ich wpływów na południowych obrzeżach Rosji). Rosja - pisał R. Kuźniar - zachowała się w sposób całkowicie przewidywalny w tym sensie, że każde inne mocarstwo w takiej sytuacji postąpiłoby dość podobnie, niezależnie od możliwych konsekwencji. Trafnie też zauważył, że w Polsce nie dostrzegano związku między wojną w Iraku, w której entuzjastycznie wzięliśmy udział, oraz uznaniem niepodległości Kosowa a wojną na Kaukazie, która w polskiej retoryce była agresją i złamaniem prawa międzynarodowego ${ }^{117}$.

Faktem było, że Polacy bali się Rosji i wyolbrzymiali zagrożenia z nią związane. Natomiast politycy rosyjscy nazbyt często lekceważyli czy wręcz bojkotowali Polskę. W ocenie Marcina Kaczmarskiego, jeśli chcemy kartę stosunków polsko-rosyjskich wypełnić realną treścią, „zacznijmy traktować Rosję jak normalne państwo, z którym czasami będzie nam po drodze (chociaż częściej te drogi się rozejda). Nie należy traktować każdego posunięcia Kremla w kategoriach etyczno-moralnych, oskarżać o neoimperializm etc. Polska od dawna rywalizuje z Rosją o Białoruś i Ukrainę tyle, że pod innymi hasłami. I ta rywalizacja nie zakończy się z dnia na dzień. Zamiast prosić Rosję o uznanie win z przeszłości, zacznijmy rozmawiać językiem Realpolitik, bo tylko taki Kreml rozumie" ${ }^{118}$. Podzielić należy stanowisko, że polityka zagraniczna Polski wobec Rosji powinna być oparta bardziej na realnych interesach, a w mniejszym stopniu na emocjach. Marek Czajkowski pisał, że wobec Rosji winniśmy realizować podejście realistyczne, akcentując dobrą wolę i podkreślając, że Polska nie chce pogarszać stosunków i dodatkowo jest gotowa do działań wspólnotowych. Percepcja Polski jako kraju, który stara się izolować i destabilizować Rosję, jest niekorzystna dla polskich interesów. Polska powinna pozostać jednym z liderów polityki wschodniej UE i starać się modelować na swą korzyść politykę Unii wobec Rosji, w taki jednak sposób, by unikać wrażenia, że nasza polityka jest antyrosyjska ${ }^{119}$. Zdaniem Romana Kuźniara, należy dążyć do uspokojenia naszych relacji z Rosją. Ze strony Rosji nie grozi nam ani energetyczny szantaż, ani militarna presja. Rosja jest słaba i nie należy mylić jej retoryki z realnymi możliwościami. „Trzeba zatem porzucić histerie i lęki, niekiedy celowo kreowane na użytek obskuranckich politycznych planów. Nie oznacza to lekceważenia Rosji. Potrzebna jest jednak gotowość do dialogu bez warunków wstępnych (co odrzucał poprzedni rząd), unikanie wygrywania kompleksów Rosji, wyzbycie się przekonania, że Polska „,nauczy Rosję demokracji i praw człowieka (to jest rola dla większych od nas). Nie możemy być także zaskoczeni ewentualną jej reakcją w odpowiedzi na

117 R. Kuźniar, Polska w czasach światowej turbulencji, „Polski Przegląd Dyplomatyczny” 2008, nr 6, s. 66-67.

118 M. Kaczmarski, Rosja na rozdrożu, Warszawa 2006, s. 172-173.

119 M. Czajkowski, Miejsce UE w polityce zagranicznej Federacji Rosyjskiej..., s. 103. 
bazę antyrakietową USA w Polsce, bo to przecież my inicjujemy zmiany w sytuacji geostrategicznej. Budowa tej bazy ma konsekwencje dla bezpieczeństwa Rosji" ${ }^{120}$. Sławomir Dębski postulował budowę polsko-rosyjskiego sojuszu strategicznego, którego istotą byłaby wspólnota interesów strategicznych Polski i Rosji w zakresie przełamywania podziałów w Europie i przyspieszania modernizacji Europy Wschodniej $^{121}$. Jednakże znaczna część polskiej klasy politycznej, przede wszystkim politycy PiS i prezydent Lech Kaczyński oraz większość polskich mediów byli zwolennikami opcji konfrontacyjnej wobec Rosji. Natomiast rząd PO/PSL skłaniał się do wizji integracyjnej Rosji z Zachodem.

Poprawa międzyrządowych relacji polsko-rosyjskich po roku 2007, z przyhamowaniem tego procesu w drugiej połowie 2008 roku, związana była m.in. z nowymi akcentami w polskiej polityce wobec Rosji, w tym z dążeniem rządu D. Tuska, by w duchu realizmu, w miejsce nieskutecznego nieprzejednania „współpracować z Rosją, taką jaką ona jest" ${ }^{\prime 22}$. W tym samym czasie wśród decydentów polityki zagranicznej Rosji coraz większą akceptacją cieszył się pogląd, że ze względu na znaczącą rolę odgrywaną przez Polskę w UE nie da się ułożyć poprawnych stosunków Rosji z państwami Europy Zachodniej bez normalizacji stosunków z Polską. Dla Rosji, rozwój stosunków z Zachodem był niezbędny dla realizacji programu modernizacji tego kraju. Rosja, osłabiona kryzysem finansowo-gospodarczym zintensyfikowała zabiegi o zacieśnienie współpracy z Zachodem. Rosyjskie grupy rządzące stopniowo uznawały, że Zachód nie jest ich wrogiem. Rosnące poczucie zagrożenia ze strony Chin było kolejnym, ważnym czynnikiem zbliżenia Rosji do Zachodu.

Na poprawę stosunków polsko-rosyjskich pod koniec pierwszej dekady XXI w. istotny wpływ miały także nowe akcenty w polityce zagranicznej administracji prezydenta Baracka Obamy, w tym przede wszystkim jego polityka „zresetowania” stosunków z Rosją. Administracja B. Obamy wykazywała mniejszą skłonność niż administracja G. W. Busha do rywalizacji z Rosją o wpływy na obszarze poradzieckim. Tym samym zmniejszyło się zapotrzebowanie po stronie amerykańskiej na koniunkturalne wykorzystywanie polskich resentymentów geopolitycznych wobec Rosji.

$\mathrm{W}$ ramach zapowiadanego przez premiera $\mathrm{D}$. Tuska $\mathrm{w}$ jego exposé $\mathrm{z}$ listopada 2007 roku wzmocnienia polskiej obecności we wschodnim wymiarze polityki wschodniej UE ${ }^{123}$, Polska i Szwecja wystąpiły wspólnie w roku 2008 z programem Partnerstwo Wschodnie, który został przyjęty przez Unię Europejską w pierwszym półroczu 2009 roku. Program objął Ukrainę, Mołdawię, Gruzję, Armenię, Azerbejdżan, z możliwością włączenia też Białorusi, o ile władze tego kraju będą wprowadzać reformy demokratyczne. Z tymi krajami Unia chciała budować strefę wolnego handlu, współpracować w celu poprawy bezpieczeństwa energetycznego, w tym w zakresie dywersyfikacji unijnych źródeł dostaw oraz tranzytu energii, wspierać budowę społeczeństwa obywatelskiego oraz sprzyjać pokojowemu rozwiązywaniu sporów. Jednakże

120 „Rocznik Strategiczny 2007/08”, Warszawa 2008, s. 19.

121 S. Dębski, Polska a modernizacyjny wybór Rosji w XXI w., „Polski Przegląd Dyplomatyczny” 2009 , nr 6 .

122 Informacja polskiego ministra spraw zagranicznych, Radosława Sikorskiego..., s. 228.

123 Exposé premiera Donalda Tuska, 23 listopada 2007 r., www.kprm.gov.pl. 
ideą przewodnią Partnerstwa Wschodniego była intensyfikacja kontaktów politycznych UE z państwami, do których była adresowana ${ }^{124}$. Partnerstwo Wschodnie było oceniane jako najambitniejszy z dotychczasowych programów wzmacniających Europejską Politykę Sąsiedztwa. Mimo że przez wielu polityków polskich było ono postrzegane jako krok objętych nim państw na drodze do członkostwa w UE, to program ten nie zawierał żadnych tego rodzaju obietnic. Kryzys finansowy, który rozpoczął się w drugiej połowie 2008 roku oraz podziały wśród państw członkowskich Unii między zwolennikami rozwijania przede wszystkim Partnerstwa Eurośródziemnomorskiego, w tym lansowanej przez Francję Unii dla Śródziemnomorza, a zwolennikami rozwoju wymiaru wschodniego Unii, wpłynął na znaczne ograniczenie środków finansowych przeznaczonych na Partnerstwo Wschodnie (ok. 600 mln euro na lata 2010-2013) oraz stosunkowo słabe zainteresowanie większości państw Europy Zachodniej realizacją tego projektu. Również zainteresowanie Partnerstwem Wschodnim ze strony rządów Polski i Niemiec wynikało z odmiennych przesłanek politycznych. O ile Niemcy - pisał J. J. Węc - ,popierały tę inicjatywę ze względu na zmiany w dotychczasowej strategii rozszerzeniowej i chęć rozwijania zdolności Unii Europejskiej do działania poza obszarem Unii, o tyle Polska traktowała ten projekt jako etap na drodze do przyszłego rozszerzenia Unii Europejskiej na Wschód"125. Charakterystyczne, że rząd kanclerz A. Merkel wraz z poparciem dla Partnerstwa Wschodniego zaangażował się w realizację projektu mającego na celu wsparcie UE dla modernizacji Rosji (Partnerstwo dla Modernizacji) ${ }^{126}$.

W dniu 10 kwietnia 2010 r. w katastrofie lotniczej pod Smoleńskiem zginęło 96 osób, w tym prezydent RP Lech Kaczyński i jego małżonka, które wraz z przedstawicielami wszystkich polskich ugrupowań politycznych reprezentowanych w Sejmie i Senacie oraz dowódcami wszystkich sił zbrojnych Wojska Polskiego udawali się na uczczenie 70. rocznicy zbrodni katyńskiej. Katastrofa polskiego prezydenckiego samolotu pod Smoleńskiem, mimo znacznego wzmocnienia postaw antyrosyjskich w tej części polskiego społeczeństwa, która nie była w stanie zaakceptować wersji niezamierzonej przez nikogo katastrofy lotniczej (wypadku lotniczego) jako przyczyny śmierci polskiego prezydenta i osób mu towarzyszących, a winą za katastrofę obarczała stronę rosyjska, nie doprowadziła do zamrożenia międzypaństwowych relacji polsko-rosyjskich. Kontynuowane były, rozpoczęte na początku 2008 r. bardziej intensywne kontakty polityczne na najwyższym szczeblu. Sprzyjała temu m.in. postępująca destalinizacja rosyjskiej historii. Ważnym przejawem tego procesu było wspólne uczczenie w dniu 7 kwietnia 2010 r. w Katyniu przez premierów Polski i Rosji, Donalda Tuska i Władymira Putina, pamięci ofiar zbrodni katyńskiej z 1940 roku. W czasie wystąpienia w Katyniu premier Rosji potępił zbrodnie reżimu stalinowskiego.

124 A. Kramer, Po co potrzebujemy nowego partnerstwa wschodniego?....

125 J. J. Węc, Relacje polsko-niemieckie w Unii Europejskiej..., s. 163. Szerzej zob. C. Ochmann, Przyszłość Partnerstwa Wschodniego z niemieckiej perspektywy, „Biuletyn Niemiecki” 2010, nr 6; E. Kaca, E. Łada, Partnerstwo Wschodnie-polska perspektywa, „Biuletyn Niemiecki” 2010, nr 6.

126 G. Westerwelle, S. Ławrow, Die deutsch - russiche Modernisierungspartnerschaft, „Frankfurter Allgemeine Zeitung" 31 V 2010. 
Minister spraw zagranicznych Polski, Radosław Sikorski przemawiając w dniu 8 kwietnia $2010 \mathrm{r}$. w polskim parlamencie opowiadał się za odpolitycznieniem problemu katyńskiego oraz innych białych i czarnych plam w historii stosunków polsko-rosyjskich $^{127}$. Natomiast w jednym z wywiadów pod koniec 2010 r. minister Sikorski stwierdził: „Rolą Polski nie jest - tak jak chciałaby tego opozycja - branie na siebie ciężaru konfrontacji z rzekomym ZSRR bis, wbrew Europie i wbrew USA. Koncepcja PiS wzięcia Rosji w stalowy uścisk w sojuszu z Litwą i Gruzją, jest nierealistyczna. Odwrotnie, powinniśmy wzmacniać procesy, które mogą, chociaż nie muszą, doprowadzić do europeizacji Rosji" ${ }^{28}$.

\section{Stanowisko Polski i Niemiec wobec dalszego rozszerzenia UE}

Różnice w polityce Polski i Niemiec wobec Rosji, występujące w relacjach dwustronnych tych państw z Rosją oraz w postulowanych przez Polskę i Niemcy koncepcjach polityki wschodniej UE, rzutowały na stanowisko Polski i Niemiec w sprawie polityki UE wobec dalszego poszerzania Unii Europejskiej. Polska opowiadała się konsekwentnie za dalszym rozszerzaniem UE. Przedstawiciele kolejnych polskich rządów deklarowali poparcie dla przyjęcia do Unii zarówno Turcji ${ }^{129}$, jak i Chorwacji ${ }^{130}$, jednakże coraz częściej uważali, że najpierw do Unii powinna zostać przyjęta Ukraina, a potem Turcja. W kwestii rozszerzenia UE największa zbieżność stanowisk Polski i Niemiec występowała w sprawie Chorwacji, której przystapienie do UE w stosunkowo krótkim czasie nie budziło w obu krajach większych wątpliwości. W przypadku Niemiec była to konsekwentna realizacja polityki prowadzonej od chwili zjednoczenia Niemiec wobec tego subregionu, w ramach której Niemcy jako pierwszy kraj Wspólnot Europejskich opowiedział się za secesją Słowenii i Chorwacji ze struktur federacji jugosłowiańskiej oraz uznał ich niepodległość w grudniu 1991 roku. Rządy Niemiec i Polski w przyjęciu Chorwacji do UE widziały ważny krok na drodze stabilizowania sytuacji na obszarze Bałkanów - jednego z kluczowych dla bezpieczeństwa europejskiego regionów. Natomiast w kwestii przystapienia Turcji do UE stanowisko Polski i Niemiec było już bardziej zróżnicowane. Po wejściu do UE Polska, podobnie jak w okresie wcześniejszym ${ }^{131}$, deklarowała poparcie dla członkostwa Turcji w UE, jed-

\footnotetext{
127 Exposé ministra Radostawa Sikorskiego wygłoszone w dniu 8 kwietnia 2010 r. w Sejmie, www.msz.gov.pl.

128 Pomóżmy Rosji się zeuropeizować. Wywiad z ministrem spraw zagranicznych Polski, Radosławem Sikorskim, „Rzeczpospolita”, 16-17 X 2010.

129 W grudniu 2004 r. UE zaprosiła Turcję do rozmów o członkostwie w Unii, zaznaczając, że w każdej chwili mogą być one przerwane, jeśli powstaną wątpliwości co do przestrzegania w Turcji praw człowieka.

130 Dnia 17 grudnia 2004 r. Rada Europejska podjęła decyzję w sprawie rozpoczęcia negocjacji akcesyjnych z Chorwacją. Ponieważ władze Chorwacji nie wypełniły w kolejnych miesiącach zobowiązań wobec Międzynarodowego Trybunału Karnego dla byłej Jugosławii, negocjacje akcesyjne Chorwacji z UE rozpoczęły się dopiero w październiku 2005 r., po spełnieniu tego warunku.

131 Jednakże także przed przystapieniem Polski do UE w stanowisku Polski wobec członkostwa Turcji w UE wyraźnie dawał znać o sobie sceptycyzm w ocenie realizacji tego projektu. Niektórzy z polskich polityków zauważali, że perspektywa członkostwa Turcji w UE może rozbudzić podobne
} 
nakże słychać było coraz częściej głosy wzywające do ostrożności. Niektórzy politycy polscy (np. Tadeusz Mazowiecki) opowiadali się za uprzywilejowanym stowarzyszeniem Turcji z UE, ale nie członkostwem ${ }^{132}$. W tym kontekście stosunkowo często przytaczano też wypowiedź kardynała J. Ratzingera (późniejszego papieża Benedykta XVI) z sierpnia 2004 roku, że Turcja w UE zuboży chrześcijańską Europę i element kulturowy, jako jeden z fundamentów integracji europejskiej, ustapiłby na rzecz gospodarki i geopolityki. W czasie wizyty w Turcji w styczniu 2007 roku prezydent Polski, Lech Kaczyński, zdecydowanie opowiedział się za członkostwem Turcji w UE, używając dla wielu kontrowersyjnego stwierdzenia, że przystapienie Turcji do Unii „Wzmocni Wspólnotę pod względem gospodarczym, terytorialnym, a także militar-

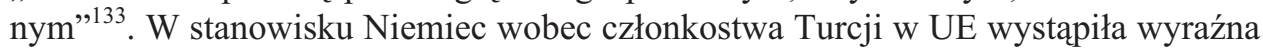
różnica w podejściu do tego zagadnienia rządu G. Schrödera i rządu A. Merkel. Rząd SPD/Sojusz90/Zieloni popierał dążenia Turcji do członkostwa w UE, natomiast rząd kanclerz A. Merkel podchodził do tego z dużym dystansem, akcentując uzależnienie tempa integracji Turcji z UE od skali przeprowadzonych wcześniej reform w UE. Politycy niemieckiej chadecji proponowali Turcji inne rozwiązanie niż pełne członkostwo, które zawierało się w formule „uprzywilejowane partnerstwo”. Tradycyjnie bowiem, czołowi politycy niemieckiej chadecji, w tym także Helmut Kohl, krytycznie oceniali propozycje członkostwa Turcji w UE, eksponując zastrzeżenia nie tylko natury ekonomicznej, ale także cywilizacyjno-kulturowej. Wstrzemięźliwe stanowisko rządu kanclerz A. Merkel wobec kolejnych rozszerzeń UE po roku 2007 (oprócz Chorwacji) wynikało także z krytycznych postaw większości Niemców co do projektów takiego rozszerzenia. Stanowisko Niemców w sprawie procesu dalszego poszerzania UE było zdecydowanie bardziej krytyczne niż Polaków (większość Niemców była przeciwna rozszerzaniu UE, natomiast zdecydowana większość Polaków opowiadała się za dalszym jej rozszerzaniem) ${ }^{134}$.

W kwestii dalszego rozszerzenia UE, w tym tempa tego procesu, największe różnice w stanowisku Polski i Niemiec występowały w odniesieniu do członkostwa Ukrainy w strukturach unijnych. Generalnie rzecz ujmując, zarówno przedstawiciele rządu G. Schrödera, jak i rządu A. Merkel, mimo występujących między nimi w tej sprawie różnic, opowiadali się za rozwijaniem wzmocnionego partnerstwa Unii z Ukrainą w celu poparcia własnych wysiłków Ukraińców na rzecz modernizacji gospodarki oraz demokratyzacji politycznej Ukrainy. Stopniowo wzrastało znaczenie Ukrainy w polityce zagranicznej UE, o czym świadczyły m.in. takie inicjatywy jak: przyjęcie 11 grudnia 1999 roku przez przywódców UE „Wspólnej strategii wobec Ukrainy”; przyjęcie

aspiracje innych państw niechrześcijańskich (np. Maroko, Izrael, Azerbejdżan), co mogłoby doprowadzić do „rozmiękczenia” kryteriów kulturowych członkostwa w Unii, a także do odrzucenia wymogu chrześcijańskich korzeni potencjalnych kandydatów do członkostwa. Zob. W. Bartoszewski, Wspólna odpowiedzialność Europy - odpowiedzialność w solidarności, w: W. Bartoszewski, Ponad podziałami. Wybrane przemówienia $i$ wywiady lipiec-grudzień 2000, Warszawa 2001, s. 104-105.

132 T. Mazowiecki, Bronić, ale nie do śmierci, „Gazeta Wyborcza”, 24 II 2004.

133 L. Kaczyński, Polska za przystapieniem Turcji do UE, „Dziennik”, 23 I 2007.

134 A. Paterek, Niemcy wobec procesu dalszego poszerzania UE, „Krakowskie Studia Międzynarodowe” 2008, nr 4 (V); P. Buras, ,Europa uda się wspólnie”. Zmiany w niemieckiej polityce europejskiej..., s. 43 i n. 
w czerwcu 2004 roku przez Radę Europejską strategii Europejskiej Polityki Sąsiedztwa; przyjęcie w styczniu 2007 roku przez ministrów spraw zagranicznych UE mandatu negocjacyjnego nowego porozumienia z Ukrainą, w którego wyniku miała powstać strefa wolnego handlu. Mimo dużego stopnia instytucjonalizacji stosunków unijno-ukraińskich ${ }^{135}$ kryzys konstytucyjny w Unii oraz kolejne fazy kryzysu politycznego na Ukrainie, w tym w obozie zwycięzców ,„pomarańczowej rewolucji”, nie sprzyjały zbliżaniu Ukrainy do Unii Europejskiej. Sytuacja wewnętrzna na Ukrainie wywierała zdecydowanie większy negatywny wpływ na stanowisko Niemiec niż Polski wobec prounijnych aspiracji części ukraińskiej klasy politycznej. Czołowi politycy niemieccy opowiadali się za zacieśnianiem współpracy gospodarczej i politycznej UE z Ukrainą, ale nie za szybkim jej członkostwem ${ }^{136}$. Taką możliwość widzieli w stosunkowo odległej perspektywie. W tym samym czasie polska dyplomacja zabiegała o to, by UE przyjęła wobec Ukrainy konkretny program członkostwa tego kraju w UE, o co zabiegał także prezydent Ukrainy, Wiktor Juszczenko. Zaangażowanie Polski na rzecz przyjęcia do UE nie tylko Ukrainy, ale także Gruzji, wzrosło jeszcze bardziej w okresie rządów PiS. W tym samym czasie rząd kanclerz A. Merkel, mimo że był mniej skłonny w stosunku do rządu G. Schrödera uwzględniać interesy rosyjskie na obszarze WNP, to jednak nie angażował się w inicjatywy podejmowane m.in. przez Polskę, których celem byłoby stworzenie Ukrainie stosunkowo bliskiej perspektywy członkostwa w UE ${ }^{137}$. Stanowisko takie tylko w części wynikało z dążenia do uwzględniania, przynajmniej w znacznym stopniu, stanowiska Rosji w procesie rozszerzania UE na obszar WNP. W jeszcze większym stopniu było ono wynikiem obaw o następstwa ekonomiczne takiego rozszerzenia oraz przekonania, że ani Ukraina, ani Gruzja nawet w średniookresowej perspektywie nie będą w stanie spełnić kryteriów kopenhaskich z 1993 roku. Polityka europejska prezydenta Ukrainy, Wiktora Juszczenki, okazała się dla większości państw członkowskich UE dużym rozczarowaniem. Jego ekipa nie wypełniła podstawowych kryteriów, których realizacja pozwoliłaby na znaczne zbliżenie się Ukrainy do Unii Europejskiej, w tym na wynegocjowanie umowy o stowarzyszeniu Ukrainy z UE czy stworzenia strefy wolnego handlu.

Polskie grupy rządzące, popierając aspiracje innych państw do członkostwa w UE, które było postrzegane przede wszystkim jako funkcja poparcia dla Ukrainy, na pierwszym miejscu stawiały rozszerzenie UE w kierunku wschodnim, przede wszystkim o Ukrainę. Politycy polscy najlepszą obronę przed neoimperialnymi tendencjami ze strony Rosji upatrywali w szybkim przyjęciu Ukrainy do UE i NATO. Członkostwo

135 P. J. Borkowski, Polityka sqsiedztwa Unii Europejskiej..., s. 214 i n.; B. Piskorska, Wymiar wschodni polityki Unii Europejskiej..., s. 323 i n.; Polityka UE wobec Ukrainy: partnerstwo czy członkostwo?, red. A. Podraza, Lublin 2006; A. Stępień-Kuczyńska, M. Słowikowski, Unia Europejska a państwa Europy Wschodniej, Warszawa 2008, s. 98 i n.; W. Priesmeyer-Tkocz, Die Europäische Union und die Ukraine. Kritische Analyse der Europäischen Nachbarschafttspolitik gegenüber der Ukraine, „Przegląd Stosunków Międzynarodowych” 2006, nr 2.

136 Nawet w czasie wizyty 21 marca 2005 r. w Kijowie ministrów spraw zagranicznych Polski i Niemiec Adama Rotfelda i Joschki Fischera, która była wyrazem poparcia dla głównych zwycięzców ,pomarańczowej rewolucji” na Ukrainie (Wiktora Juszczenki i Julii Tymoszenko) nie mówiono wprost o członkostwie Ukrainy w UE, ale o planach zbliżenia Ukrainy do UE.

137 Szerzej zob. B. Koszel, Polska i Niemcy w Unii Europejskiej..., s. 96-120. 
Ukrainy w UE było traktowane jak główny cel strategiczny Polski w kwestii dalszego rozszerzenia Unii. Po stronie polskiej, w przeciwieństwie do niemieckiej, przywiązywano mniejszą wagę do skutków takiego kroku dla dynamiki integracji europejskiej. W polityce integracyjnej Niemiec sprawom związanym z ewentualnym członkostwem Ukrainy w UE nie nadawano rangi celu priorytetowego ${ }^{138}$. Rząd kanclerz A. Merkel opowiadał się za wzmocnieniem i rozwojem Europejskiej Polityki Sąsiedztwa, zwłaszcza jej wschodniego wymiaru, w formie Partnerstwa Wschodniego, ale bez przyjmowania konkretnych zobowiązań co do członkostwa Ukrainy czy innych państw w UE ${ }^{139}$. Wybuch konfliktu kaukaskiego w sierpniu 2008 roku wzmocnił także w Niemczech argumentację zwolenników przejęcia przez Unię Europejską większej odpowiedzialności za regiony przylegające do jej wschodnich granic. Partnerstwo Wschodnie rząd RFN widział jako nowy impuls dla Europejskiej Polityki Sąsiedztwa na kierunku wschodnim służący stabilizacji i rozwojowi współpracy z wschodnioeuropejskimi sąsiadami ${ }^{140}$.

Rząd niemiecki wspierał polityczne i gospodarcze reformy na Ukrainie i dążenia tego kraju do zacieśniania współpracy z UE, ale bez składania konkretnych obietnic co do członkostwa Ukrainy w UE. W stanowisku Niemiec wobec dalszego poszerzania UE kluczową rolę odgrywały argumenty ekonomiczne i argumenty dotyczące zdolności absorpcyjnych Unii, w tym efektywności struktur unijnych, do przyjęcia nowych państw. Natomiast w stanowisku Polski w tej sprawie główną rolę odgrywały argumenty geostrategiczne (wzrost bezpieczeństwa) oraz kulturowo-historyczne. W przeciwieństwie do Polski, Niemcy nie próbowały „rozgrywać” Ukrainy przeciwko Rosji. W doktrynie integracyjnej Polski akcent był postawiony na poszerzenie Unii, przede wszystkim o Ukrainę. W polityce integracyjnej Niemiec, po rozszerzeniu w latach 2004-2007, priorytet miała zasada „najpierw pogłębienie, a ewentualnie później poszerzenie". Z sondażu Eurobarometru przeprowadzonego jesienią 2007 roku wynikało, że ponad 3/4 Polaków (76\%) popierało przyłączenie do Unii kolejnych państw. Był to najwyższy wynik poparcia dla rozszerzania UE wśród państw członkowskich ${ }^{141}$. W tym samym czasie zdecydowana większość Niemców opowiadała się przeciwko dalszemu rozszerzeniu $\mathrm{UE}^{142}$.

W wyborach prezydenckich na Ukrainie przeprowadzonych na początku $2010 \mathrm{r}$. zwyciężył Wiktor Janukowicz, polityk, przeciwko któremu występowali czołowi polscy politycy zaangażowani w ukraińską ,pomarańczową rewolucję”. Nowy prezydent

138 W. Priesmeyer-Tkacz, Niemcy wobec Europejskiej Polityki Sasiedztwa..., s. 278 i n.; A. Szymański, Polska wobec dalszego poszerzania Unii Europejskiej, „Krakowskie Studia Międzynarodowe" 2008, nr 4 (V).

$139 \mathrm{~W}$ dniu 24 kwietnia 2008 r. w przemówieniu na forum Bundestagu kanclerz A. Merkel powiedziała m.in., że w najbliższym czasie, z wyłączeniem krajów bałkańskich, nie możemy składać nowych obietnic dotyczących członkostwa. Zaznaczyła, że dotyczy to także Ukrainy. Jestem przekonana, mówiła kanclerz A. Merkel, że najpierw należy podjąć wysiłki, aby zagwarantować Unii zdolność do działania i konkurencji. Rede von Bundeskanzlerin Merkel zum EU-Reformvertrag im Bundestag, 24 IV 2008, www.bundeskanzlerin.de/nn_5296/Content/DE/Rede/2008/04/2008-04-24-merkel-bt-lissabonvertrag.html.

140 G. Gloser, Zarys nowej polityki wschodniej UE, „Dialog” 2008-2009, nr 85-86.

141 A. Szymański, Polska wobec dalszego poszerzania Unii Europejskiej..., s. 192.

142 A. Peterek, Niemcy wobec procesu dalszego rozszerzania UE..., s. 208. 
Ukrainy deklarował, że Ukraina będzie współpracować z NATO, ale do niego nie wstapi. Według niego Ukraina musi pozostać poza blokami wojskowymi, gdyż opowiedzenie się po którejś stronie zwiększy zagrożenie bezpieczeństwa narodowego i napięcia w stosunkach międzynarodowych. Nowa administracja Ukrainy deklarowała wolę zacieśnienia stosunków zarówno z Rosją ${ }^{143}$, jak i z Unią Europejską. Prezydent Polski, Bronisław Komorowski, w jednym $z$ wywiadów stwierdził, że nowe grupy rządzące Ukrainą nie chcą być zachęcane do wyboru z Rosją czy z Zachodem, bo stoją na stanowisku, że można i z jednymi, i z drugimi żyć dobrze. Wspomagając Ukrainę w jej drodze na Zachód - mówił prezydent Komorowski - trzeba pokazywać, że współpraca z UE i Polską nie wiąże się z koniecznością złych relacji z Rosją ${ }^{144}$.

Zaangażowanie się Polski w realizację projektu Partnerstwa Wschodniego oceniane było przez niektórych analityków spraw międzynarodowych jako początek odchodzenia Polski od priorytetowego traktowania Ukrainy, na rzecz prowadzenia polityki wschodniej wobec sześciu państw poradzieckich (Ukrainy, Białorusi, Mołdawii, Gruzji, Azerbejdżanu i Armenii) i to nie samodzielnie, ale w formule zewnętrznej polityki Unii Europejskiej. Przy jednoczesnym bardziej pragmatycznym ułożeniu stosunków polsko-rosyjskich, polska polityka wobec Ukrainy traciła dotychczasowy podtekst antyrosyjski ${ }^{145}$.

\section{Zakończenie}

Mimo intensyfikacji wysiłków podejmowanych w pierwszym dziesięcioleciu XXI wieku zmierzających do wypracowania spójnej polityki wschodniej UE, jej efektywność w praktyce była nadal stosunkowo niska, podobnie zresztą jak na innych kierunkach realizowanej przez Unię WPZiB. Nadal polityka poszczególnych państw członkowskich UE wobec Rosji, Ukrainy, Białorusi czy Gruzji była bardziej efektem ich indywidualnych przedsięwzięć w tym zakresie niż konsekwentnie realizowanych wspólnych uzgodnień $w$ ramach polityki wschodniej UE. W tym kontekście pojawiały się opinie, że największym problemem stojącym przed UE w relacjach z Rosja jest brak jedności ${ }^{146}$. Zdolność UE do wytyczenia i realizacji wspólnej polityki wschodniej zależała w dużym stopniu od stopnia zbieżności wizji tej polityki Polski i Niemiec, i praktycznych działań podejmowanych w tym zakresie przez oba państwa. Jednakże różnice w postrzeganiu Rosji przez grupy rządzące obu państw, nie tylko w okresie rządów G. Schrödera, ale także w czasie rządów ,wielkiej koalicji”, były nadal bardzo znaczące ${ }^{147}$.

Po rozszerzeniu UE w roku 2004 wzrosły różnice między państwami członkowskimi w poglądach na kształt polityki UE, jako całości, wobec Rosji, Ukrainy, Białorusi

143 Jednym z najbardziej wymownych tego przykładów było nowe porozumienie ukraińsko-rosyjskie przedłużające stacjonowanie rosyjskiej Floty Czarnomorskiej na Krymie do roku 2042.

${ }_{144}$ Z Ukraina bez zmian. Wywiad z prezydentem RP, Bronisławem Komorowskim, ,, Rzeczpospolita”, 6 X 2010.

145 R. Zięba, Główne kierunki polityki zagranicznej Polski po zimnej wojnie, Warszawa 2010.

146 M. Leonard, N. Popescu, Rachunek sit...

147 A. Guział, Miejsce Rosji w polityce zagranicznej RFN a szansa na wspólna politykę wschodnia UE, „Przegląd Zachodni” 2006, nr 2; B. Sienkiewicz, Gesty i zmiany, „Dialog” 2005-2006, nr 72-73. 
czy Gruzji. Różnice te występowały także w koncepcjach polityki wschodniej UE prezentowanych przez Niemcy i Polskę. Mimo ewolucji polityki niemieckiej wobec Rosji, w kierunku relacji bardziej pragmatycznych, Niemcy zainteresowane były w polityce wschodniej UE przede wszystkim rozwojem wszechstronnej współpracy z Rosją. Mimo skomplikowanej historii, stosunki niemiecko-rosyjskie nie były obciążone historycznym balastem i rozliczeniami w takim stopniu, jak stosunki polsko-rosyjskie. Grupy rządzące Niemiec priorytetowo traktowały relacje z Rosją i płaszczyznę gospodarczą tej współpracy. W polskiej koncepcji relacji dwustronnych z Rosją i proponowanej przez Polskę polityki wschodniej UE rozwój stosunków z Rosją wiązano $\mathrm{w}$ dużym stopniu z przestrzeganiem praw człowieka w Rosji, rozwiązaniem dwustronnych problemów polsko-rosyjskich i charakterem polityki rosyjskiej na obszarze WNP. Dla Polski, priorytetem w polityce wschodniej UE powinna być nie Rosja, lecz Ukraina, co wynikało też z prometejskiej koncepcji polskiej polityki wschodniej, zmodyfikowanej po II wojnie światowej przez środowisko „Paryskiej Kultury” ${ }^{148}$. W ramach polityki wschodniej UE Polska postrzegała Rosję przede wszystkim jako konkurenta i główne zagrożenie w regionie. Natomiast w niemieckiej hierarchii priorytetów na kierunku wschodnim była Rosja. W niemieckim postrzeganiu Rosji dominowała wizja Rosji jako partnera, a nie rywala, akcent kładziony był na współprace z Rosją, a nie rywalizację. Jeśli na wschodzie niemal w całym omawianym okresie Niemcy dostrzegali przede wszystkim interesy Rosji („najpierw Rosja”), to po stronie polskiej eksponowano potrzebę respektowania interesów ukraińskich („,najpierw Ukraina”). Kai-Olaf Lang pisał, że wszelkie rozważania wokół „polityki wschodniej”, zarówno w Niemczech, jak i w Polsce, koncentrują się na Rosji. Jednakże podczas gdy Niemcy traktują Rosję jako pierwszoplanowego partnera współpracy politycznej i gospodarczej, to polski rusocentryzm manifestuje się w polityce „Ukraine first” i w dążeniu do ograniczenia supremacji Rosji na obszarach postsowieckich ${ }^{149}$. Zabieganie Polski o członkostwo Ukrainy w NATO i UE niekiedy było silniejsze niż samej dyplomacji ukraińskiej. Nowe akcenty w polskiej polityce wobec Ukrainy pojawiły się w roku 2009, a w jeszcze większym stopniu na początku 2010 roku. Związane to było $\mathrm{z}$ rosnącym rozczarowaniem polskiej klasy politycznej wobec liderów ${ }^{150}$ i efektów ukraińskiej „pomarańczowej rewolucji”. Zaczęły pojawiać się komentarze, w których wskazywano na potrzebę prowadzenia wobec Ukrainy mniej emocjonalnej, a bardziej spokojnej i rozważnej polityki ${ }^{151}$.

148 S. Garsztecki, Rosja w Europie - polska i niemiecka percepcja Rosji-analiza porównawcza, w: Międzynarodowe implikacje procesu integracji europejskiej dla Polski i Niemiec..., s. 206.

149 K.-O. Lang, Niemcy i Polska w Unii Europejskiej: „, od wspólnoty interesów” do „, konstruktywnych rozbieżności”, w: Polska - Niemcy - Francja. Wzajemne postrzeganie po rozszerzeniu UE, red. L. Kolarska-Bobińska, M. Fałkowski, Warszawa 2008, s. 112.

${ }_{150}$ Wielu polskich polityków i komentatorów dopiero pod koniec kadencji prezydenckiej Wiktora Juszczenki dostrzegło nacjonalistyczny charakter prowadzonej przez niego polityki historycznej kiedy to kończący kadencję prezydencką W. Juszczenko nadał na początku 2010 r. Stepanowi Banderze tytuł bohatera Ukrainy i uznał Ukraińską Powstańczą Armię (UPA) i Organizację Ukraińskich Nacjonalistów za uczestników walk o niepodległość państwa.

151 Zob. R. Kuźniar, Polska - Ukraina. Czas skończyć z romantyzmem, „Dziennik. Gazeta Prawna”, 26 I 2010. 
Mimo licznych problemów występujących w stosunkach niemiecko-rosyjskich i unijno-rosyjskich, wielu polityków niemieckich, krytykując rozwiązania z użyciem siły militarnej, skłaniało się ku akceptacji roli Rosji jako swego rodzaju stabilizatora sytuacji na obszarze byłego Związku Radzieckiego. Polska eksponowała zazwyczaj rolę Rosji na obszarze WNP jako głównego destabilizatora ${ }^{152}$. Przemysław Żurawski vel Grajewski pisał, że dla Polski, w polityce wschodniej UE najważniejsza była okcydentalizacja Ukrainy, Białorusi, Mołdawii i Gruzji, za co Rzeczpospolita jest gotowa (a w każdym razie powinna być) zapłacić cenę w postaci konfliktu politycznego z Rosja. Dla Niemiec priorytetem były dobre stosunki z Rosja, nawet gdyby ceną za nie miało być uznanie jej dominacji na obszarze między poszerzoną Unią a Federacją Rosyjską $^{153}$. Wśród niemieckich analityków spraw międzynarodowych pojawiały się nawet głosy akceptacji dla posiadania przez Rosję własnej strefy wpływów na obszarze byłego ZSRR ${ }^{154}$.

Budowa rosyjsko-niemieckiego gazociagu po dnie Bałtyku traktowana była w RFN jako pożądana dywersyfikacja tras przesyłowych i źródeł zaopatrzenia gospodarki niemieckiej w surowce energetyczne. W Polsce budowa gazociagu bałtyckiego była oceniana jako bardzo poważne zagrożenie jej bezpieczeństwa energetycznego ${ }^{155}$ i jako przykład odejścia polityków niemieckich od składanych zapewnień, że strategiczne partnerstwo z Rosją budowane będzie w porozumieniu z Polską.

Interesy gospodarcze i dążenie do stabilizowania sytuacji na obszarze WNP spychały po stronie niemieckiej na dalszy plan dążenie do oparcia relacji niemiecko-rosyjskich na wspólnych wartościach dotyczących demokracji, państwa prawa i poszanowania praw człowieka (wspólnota interesów przed wspólnotą wartości). W ramach dwóch głównych postaw, które dominowały wśród państw członkowskich UE wobec Rosji, Niemcy zaliczane były do najważniejszego reprezentanta tej grupy państw, które opowiadały się za realizacją wobec Rosji tzw. doktryny pełzającej integracji. Jej zwolennicy, w tym minister spraw zagranicznych Niemiec w latach 2005-2009, Frank-Walter Steinmeier, uważali Rosję za partnera i byli za tym, by jak najściślej wiązać Rosję z politycznymi i ekonomicznymi strukturami unijnymi, co sprawi, że Rosja stopniowo stanie się liberalną demokracją (formuła „Wandel durch Verflechtung” - zmiana przez powiązanie $)^{156}$. W ocenie niemieckiej powolny proces demokratyzacji Rosji jest możliwy wyłącznie dzięki współpracy, a nie w wyniku odgraniczania się. W tym czasie Polskę zaliczano zaś do lidera grupy państw, które widziały w Rosji przede wszystkim wroga i tak też ją traktowały. Według Polski i pozostałych państw tej grupy rosyjski ekspansjonizm i lekceważenie demokracji należało ukrócić przez politykę „łagodnego

152 Zob. Ch. B. Scheffel, Niemcy i Polska wobec Rosji...; E. Cziomer, Europejski wymiar polityki Niemiec...; D. Bingen, Niemcy, Polacy i ich sqsiedzi na wschodzie...

153 P. Żurawski vel Grajewski, Polityka wschodnia Unii Europejskiej a interesy Polski, w: Polityka zagraniczna Polski. Unia Europejska, Stany Zjednoczone..., s. 32.

154 Zob. wywiad z Michaelem Stürmerem, „Dziennik”, 28 II-1 III 2009.

155 Minister obrony narodowej RP, Radosław Sikorski, porozumienie Niemcy-Rosja w sprawie gazociągu na dnie Bałtyku porównał nawet do paktu Ribentrop-Mołotow.

156 Termin ten był nawiązaniem do formuły „Wandel durch Annäherung” - zmiany przez zbliżenie, która obowiązywała w polityce zachodnioniemieckiej socjaldemokracji wobec państw bloku wschodniego od połowy lat sześćdziesiątych XX w. 
powstrzymywania", której elementami powinny być m.in.: wykluczenie Rosji z grupy G-8, dalsze poszerzanie NATO (w tym o Ukrainę i Gruzję), poparcie dla antyrosyjskich rządów na obszarze WNP, budowa tarczy antyrakietowej, tworzenie ,energetycznego NATO" oraz wyłączenie rosyjskich inwestycji z europejskiego sektora energetycznego ${ }^{157}$. W niemieckiej polityce wobec Rosji pierwszym etapem jej realizacji było takie zacieśnienie politycznych, gospodarczych i kulturalnych związków z Rosją, aby jej zakotwiczenie w Europie uczynić nieodwracalnym. Wzmacniałoby to tendencje demokratyczne w Rosji, dzięki czemu między Rosją i UE mogłoby powstać również „partnerstwo wartości" ${ }^{\text {"158 }}$. Natomiast znaczna czę́ś polskich elit politycznych i intelektualnych uważała, że warunkiem rozwoju stosunków z Rosją powinno być przyjęcie przez nią najpierw zachodniego systemu wartości, w tym unijnych standardów w zakresie praw człowieka, ustroju politycznego i zasad gospodarki rynkowej.

W niemieckiej myśli politycznej dominowało stanowisko włączania Rosji w coraz to nowe formy współpracy europejskiej ${ }^{159}$, natomiast w polskiej - bardzo dużym uznaniem cieszyło się stanowisko izolowania Rosji. Jak już zostało wspomniane, po zmianie rządów w Polsce jesienią 2007 roku polskie ministerstwo spraw zagranicznych, kierowane przez ministra Radosława Sikorskiego, prowadziło wobec Rosji bardziej pragmatyczną politykę $\mathrm{w}$ stosunku do polityki polskich ekip rządzących $\mathrm{w}$ okresie wcześniejszym. Nowe podejście polskiej dyplomacji wobec stosunków z Rosją oparte zostało na formule „będziemy współpracować z Rosją, taka, jaką ona jest”. Formuła ta została nieco zmodyfikowana po wojnie gruzińsko-rosyjskiej w sierpniu 2008 roku. W relacjach z Rosją utrzymany został jednak kierunek na dialog i wymianę argumentów, przy zachowaniu woli walki o podstawowe interesy naszego kraju ${ }^{160}$. Procesu tego nie przerwała także katastrofa polskiego prezydenckiego samolotu pod Smoleńskiem.

Rozpoczęty pod koniec 2007 r. nowy etap polskiej polityki wschodniej obejmował stopniowo kolejne obszary, prowadząc do modyfikacji dotychczasowej polityki wobec Rosji, Ukrainy, Białorusi i Gruzji w oparciu o tzw. pozytywny realizm. Zmiany jakie zachodziły pod koniec pierwszej dekady XXI w. w polskiej polityce wschodniej dotyczyły nie tylko praktyki, ale także sfery koncepcyjnej. Jednym z tego przejawów były zgłaszane postulaty odejścia od występujących w polskiej myśli politycznej kolejnych modyfikacji koncepcji jagiellońskiej i prometejskiej, u podstaw których leżało nastawienie antyrosyjskie i postawa misyjności wobec wschodnich sąsiadów. Pojawiły się propozycje odejścia od nieefektywnych ,jagiellońskich ambicji mocarstwowych”, budowania przeciwwagi pod przywództwem Polski, by równoważyć przewagę Rosji. Jednym z ważnych wątków tej dyskusji był także spór wokół interpretacji koncepcji określanej akronimem ULB (Ukraina, Litwa, Białoruś) sformułowanej przez Juliusza Mieroszewskiego i Jerzego Giedroycia oraz jej współczesnego, adekwatnego do istniejących realiów, odczytywania.

157 M. Leonard, N. Popescu, Rachunek sił...

158 B. Koszel, Stosunki Polska-Niemcy a bezpieczeństwo europejskie, w: Polska-Niemcy 1945-2007. Od konfrontacji..., s. 257.

159 Zob. A. Rahr, Kein Europa ohne Russland, „Internationale Politik” 2009, Nr. 1.

160 Wystapienie ministra spraw zagranicznych Polski, Radostawa Sikorskiego w Sejmie w dniu 13 lutego 2009 r., http://www.platforma.org./print/. 
Zmiany wprowadzone do polskiej polityki wschodniej pod koniec pierwszej dekady XXI w. znacznie zbliżyły ją do polityki wschodniej RFN. Rząd PO/PSL, nie rezygnując z roli dobrego adwokata interesów Ukrainy w UE, skłaniał się stopniowo w polityce wschodniej ku uznaniu Rosji za głównego partnera nie tylko gospodarczego, ale także w płaszczyźnie politycznej i bezpieczeństwa. W polskiej polityce wobec Rosji umacniała się też w tym czasie tendencja, dominująca od wielu lat w polityce RFN wobec Rosji, do jak najściślejszego wiązania Rosji z politycznymi i ekonomicznymi strukturami unijnymi i euroatlantyckimi (europeizacji Rosji), co powinno sprzyjać ewolucji systemu ekonomiczno-politycznego Rosji w kierunku rozwiązań charakterystycznych dla liberalnej demokracji. Poprawa stosunków polsko-rosyjskich była zgodna z oczekiwaniami naszych głównych partnerów w UE i NATO, wpływała na umocnienie naszej pozycji w relacjach z nimi, sprzyjała stopniowej europeizacji Rosji oraz zbliżaniu Ukrainy, Białorusi i Gruzji do różnych form stowarzyszenia z UE. Podzielić należy stanowisko, że Polska będzie wywierać tym większy wpływ na politykę wschodnią UE, im lepsze będą relacje nie tylko polsko-niemieckie, ale także polsko-rosyjskie. Brzmi to paradoksalnie - pisał Cornelius Ochmann - ale najlepsze poparcie dla przyjęcia Ukrainy do UE można uzyskać poprzez poprawę stosunków Polski z Rosją ${ }^{161}$.

161 C. Ochmann, Panorama wschodnioeuropejska, „Dialog” 2009, nr 89, s. 46. 
